\title{
A first comprehensive inventory of Ascalaphidae, Palparidae, and Myrmeleontidae (Insecta: Neuroptera) of Northeastern Nigeria with description of two new species and an overview of genus Bankisus Navás
}

\author{
André Prost ${ }^{1}$, Alexi Popov ${ }^{2}$ \\ (1) [Corresponding author] 1 Rue de l'Eglise, 39320 Loisia, France, \\ andre.prost@free.fr $\square$; https://orcid.org/0000-0002-6002-1933 [ \\ (2) National Museum of Natural History, Bulgarian Academy of Sciences, 1 Tsar Osvoboditel Blvd, 1000 Sofia, Bulgaria, \\ alpopov@nmnhs.com $\square$; https://orcid.org/0000-0001-9448-0735 [ \\ http://zoobank.org/F3493CAB-6B27-40F5-921B-FFA809F223A3 ־
}

\begin{abstract}
Investigation of a large collection of Neuroptera from Northeastern Nigeria stored untouched in alcohol for four decades in the National Museum of Natural History, Sofia, provided the opportunity to examine unpublished specimens and conduct a thorough review of published literature, establishing the first comprehensive inventory of Ascalaphidae, Palparidae, and Myrmeleontidae of Northeastern Nigeria to date. Specimens had been collected between 1976 and 1978 in Northeastern Nigeria, mostly in Jos City and Plateau State. Five species of Ascalaphidae, four of Palparidae, and 26 of Myrmeleontidae were identified. Bankisus beroni sp. n. and Creoleon nigrithorax sp. n. are described. Gymnoleon gaillardi is not considered a synonym of Gymnoleon exilis and a new synonymy is established: Gymnoleon externus (Navás, 1911) (= Gymnoleon gaillardi Navás, 1912, syn. n.). An examination of unpublished specimens in museum collections and an exhaustive literature review were conducted in order to draw up a comprehensive inventory of the fauna of Northeastern Nigeria, which to date comprises 11 species of Ascalaphidae, 12 species of Palparidae, and 34 species of Myrmeleontidae, of which one species of Ascalaphidae, two species of Palparidae, and 16 species of Myrmeleontidae, as well as the genera Brevibarbis, Bankisus, and Capicua, had not been reported to occur in Nigeria. The chorological information on the genus Bankisus is reviewed, the ranges of the species are critically discussed and corrected, and all known localities are indicated on a map. Bankisus oculatus is reported for the first time from the Democratic Republic of the Congo. The first recording of Centroclisis lineatipennis in West Africa is reported. Palpares cataractae and Palpares radiatus are deleted from the list of Nigerian fauna. With these new records, the known ranges of eight species are extended by more than $1400 \mathrm{~km}$. In the process of assessing the geographical distribution of species present in Northeastern Nigeria, six species, as well as the genera Myrmecaelurus and Cueta and the tribe Nesoleontini, are reported for the first time from Burkina Faso.
\end{abstract}

Keywords: Myrmeleontoidea, Neuropterida, new synonym, new taxa, Sudan savannah species, West Africa

\section{Introduction}

Nigeria is the largest and most geophysically diverse country in West Africa, with climatic zones ranging from arid Sahelian regions in the North to rain forest in the Southeast. Most of the country is situated in the Sudan savannah zone with an annual rainfall between 700 $\mathrm{mm}$ and $1200 \mathrm{~mm}$, and in the Guinean savannah zone with over $1200 \mathrm{~mm}$ annual rainfall. Rain forest areas are residual.

Nigeria has a rich species diversity of Neuroptera. In a literature review of the antlions and owlflies of West Africa from Senegal to Nigeria, Michel and Akoudjin listed 20 species of Palparidae, 98 species of 


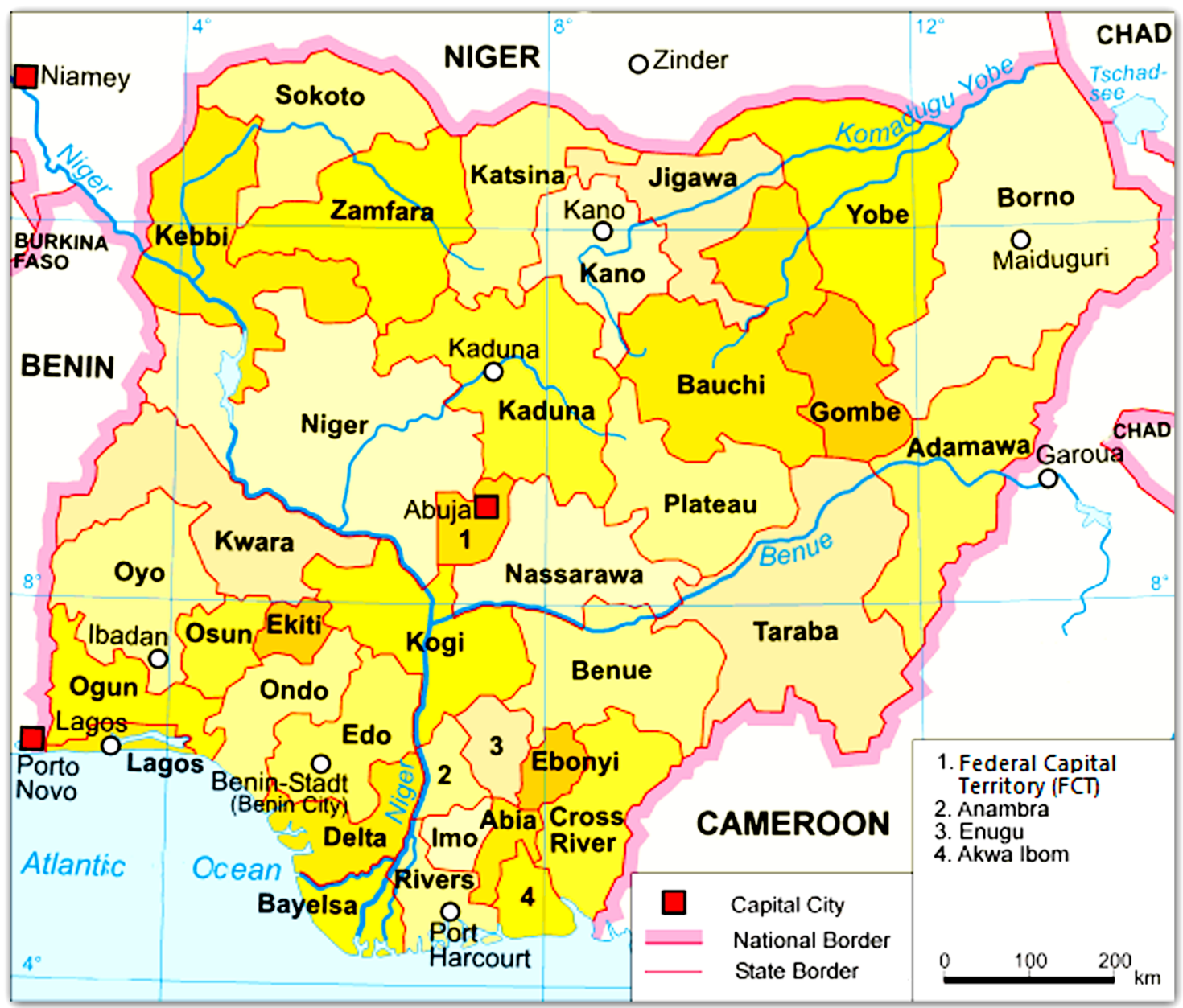

Fig. 1. Administrative map of Nigeria.

Myrmeleontidae and 24 species of Ascalaphidae, of which 12 species of Palparidae, 35 species of Myrmeleontidae and 16 species of Ascalaphidae that were reported to occur in Nigeria (Michel \& Akoudjin, 2013). Yet very few can be attributed to a specific region of this immense country. Old inventories (Walker, 1853; Hagen, 1866) lack the necessary precision. The most recent and frequent reference provided to extend to Nigeria the distribution of many species does not provide either a regional breakdown nor any time frame for specimen collections (Medler, 1980). In fact, the vast majority of specimens have been collected in the southern part of the country and in the Adamawa Mountains, close to the Cameroon border, the richest region in terms of quantity and diversity, and a part of the country which has been better investigated. Northern Nigeria has been poorly investigated.

Based on the material collected by Petar Beron, we sought to review the fauna of the three families of
Neuroptera found in Northeastern Nigeria, a region of elevated plateaus, $1000 \mathrm{~m}$ and higher, north of the Niger and Benue River valleys and east of longitude $8^{\circ} \mathrm{E}$. It includes the federal states of Borno, Yobe, Gombe, Bauchi, Jigawa, and Plateau (Fig. 1). The cities of Jos $\left(9^{\circ} 56^{\prime} \mathrm{N}, 8^{\circ} 53^{\prime} \mathrm{E}\right)$, Plateau State, and Maiduguri $\left(11^{\circ} 50^{\prime} \mathrm{N}, 13^{\circ} 09^{\prime} \mathrm{E}\right)$, Borno State, are the main administrative centres. Records from Kano, Kaduna, and Niger states are also mentioned when appropriate, because of the similarity of the ecological and climatic conditions, although they are situated outside the limits of our study area. The region is a Sudan savannah area turning to arid on the border with the Republic of Niger. Parts of Taraba and Adamawa states that are located on the northern bank of the Benue River are also included in this review.

Henwood published the unique inventory that deals specifically with Northern Nigeria: it lists two Ascalaphidae, three Palparidae, and eight Myrmeleon- 
tidae (Henwood, 1977). An inventory of the fauna of Wase Rock, a natural reserve in Plateau State (also visited by Petar Beron) does not mention any Neuroptera in the list of insects recorded (Dunger, 1965).

An inventory of the collection of Neuropterida in the National Museums of Scotland, Edinburgh, reported 41 species from Nigeria, unfortunately without details about the location of the catching stations (Whittington, 2002). We were permitted by the curator to examine this collection which is significant because the material from Nigeria ranks third in the number of species of 64 countries and regions on all continents deposited in Edinburgh.

We propose a comprehensive inventory of the fauna of Ascalaphidae, Palparidae, and Myrmeleontidae in Northern Nigeria, based on the Sofia Museum material, with reference to other information available in the literature, complemented with relevant material present in public or private collections and unpublished to date. The inventory updates and corrects a number of identifications proposed by Henwood (1977).

\section{Material and methods}

A total of 296 specimens were collected in Nigeria by Dr P. Beron between 3 July 1976 and 9 December 1978, mainly by attraction to light. They were preserved in alcohol, stored in individual laboratory tubes soon after collection, given temporary labels, and sent periodically in shipments by mail to the National Museum of Natural History. In Sofia, the temporary labels were replaced with permanent India ink labels, and 15 to 20 tubes closed with cotton plugs were placed in lots in glass jars filled with alcohol by the second author. These jars were kept untouched from 1978 to 2016. After a quick inventory in Sofia by both authors in 2013, it was decided to take the time for a more thorough study. The entire collection of specimens was mailed on loan to the first author in 2016 for preparation and identification. All specimens, with few exceptions, were removed from alcohol, dried superficially on blotting paper to unfold and flatten the wings, then prepared as dry specimens pinned with wings spread. During the entire process, transport, and preparation, no more than 20 specimens suffered significant damage and in no case did it hamper their identification. Identification was made by the first author in 2017-2018 and the entire collection was safely brought back by road to Sofia in museum boxes in July 2018 .
Two specimens in the collection of the first author were added to the material, one originating from Northern Nigeria, and one from Burkina Faso as type material of the new species of Creoleon.

Samples from Northern Nigeria, published originally by Whittington (2002) without locality, and revisited for the purpose of adding data on localisation by the first author and Andrew Whittington, supplemented the information on the species concerned.

The genitalia of the holotype and paratype of Bankisus beroni $\mathbf{s p .} \mathbf{n}$. were macerated and illustrated in Sofia by the second author. The apex of abdomen of each was cleared in boiling $10 \% \mathrm{KOH}$ (potassium hydroxide) solution for 1-2 minutes, rinsed in water, and preserved in glycerol. The figures of the genitalia of the new Bankisus were made by hand drawing under Zeiss Stemi 2000-C Stereo Microscope, using photographs taken with Zeiss AxioCam ERc 5s Microscope Camera. Photographs of specimens were taken with Sony SLT-A77V camera.

The terminology of the genitalia follows that of Aspöck \& Aspöck (2008). A comparison with the other names of the genital sclerites used in Myrmeleontidae is given after the description of Bankisus beroni $\mathbf{s p .} \mathbf{n}$.

Several authors have undertaken a revision of the higher systematics of the Neuropterida (families, subfamilies, tribes) based on molecular biology studies, DNA analyses, and phylogenetic studies. Research is ongoing, expected to lead to a scientific consensus which has not yet been achieved. Badano et al. (2017) based their phylogenetic analysis of Myrmeleontiformia on the morphology and behaviour of the larvae and found no confirmation of the monophyly of Ascalaphidae, but still considered it as a separate family. Winterton et al (2017) called into question the status of Ascalaphidae as a family. Machado et al. (2018) went even further. They consider Ascalaphidae as a paraphyletic lineage within Myrmeleontidae, lowering its rank to the subfamily Ascalaphinae, and downgrading its former subfamilies to tribes. Moreover, subfamily Ascalaphinae would also include Palparini and a few other antlion tribes in the new conceptualisation. The conclusions are still debated by scientists. There is the view that a larger range of specimens needs to be included in the overall analysis before such a shake up of the nomenclature is considered. In addition, the scarcity of Afrotropical specimens, compared with the large number of Neotropical species investigated may raise doubts about the universal nature of the proposed conceptualisation. The reason for important discrepan- 
cies between analyses has not yet been sorted out in a satisfactory manner.

Whereas we agree that the new architecture of Neuropterida may finally shape a renewed scientific consensus, in this paper we lean to the conservative side. Until there is definitive evidence to the contrary, we therefore accept the conclusions of Jones (2019), who maintains Ascalaphidae as a separate family based on morphological and also molecular data, and considers it as a monophylum. We also accept his interpretation of Palparidae as a distinct family.

Concerning Myrmeleontidae, we follow the classification of Michel et al. (2017) and the proposed subdivision into subfamilies and tribes.

\section{Results}

Based on a background review of publications that mention Northern Nigeria in relation to identified Neuroptera on the occasion of investigating and identifying an exceptional collection by Dr Petar Beron that yielded five species of Ascalaphidae, four species of Palparidae, and 26 species of Myrmeleontidae, we drew up the most comprehensive inventory of the fauna of Northeastern Nigeria to date. This inventory is also a first for the region. It reveals clearly the importance of the data collected by P. Beron and the contribution of his collection to a regional fauna that had been largely unexplored. We present the inventory below.

\section{ASCALAPHIDAE \\ Haplogleniinae}

Tmesibasini

\section{Tmesibasis royi Tjeder, 1980}

The revision of the genus Tmesibasis by Jones (2014) includes a male from Yobe State. All other specimens come from The Gambia, Senegal, and Burkina Faso.

Tmesibasis waelbroecki Van der Weele, 1909

Henwood (1977: Fig. 2) published a photo of a male from Toro, Bauchi State, 24.IX.1973. It is a widespread

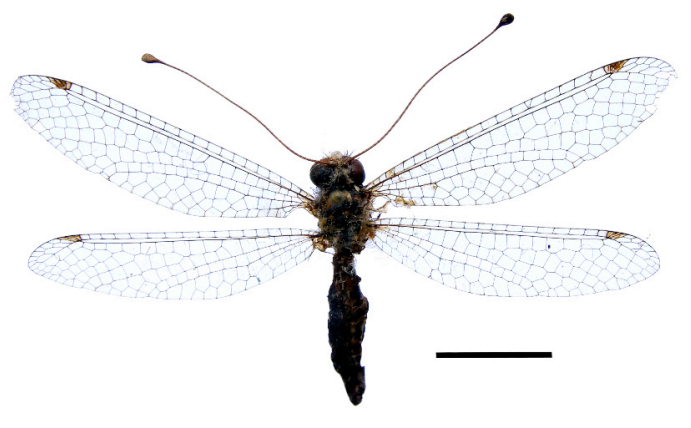

Fig. 2. Brevibarbis argyroptera $q$ from Panyam, 13.III.1978. Scale bar: $1 \mathrm{~cm}$.

species in humid savannahs north of the Congo River Basin, from Côte d'Ivoire to Uganda.

Material: Pandam Wildlife Park, Plateau State, 1 đ, 1.X.1978.

Ascalaphinae

Ascalaphini

Ascalaphus festivus (Rambur, 1842)

This is a common species in West Africa, mentioned by Medler (1980) for Nigeria as Helicomitus festivus and by Whittington (2002) for Northern Nigeria. Several specimens from Northern Nigeria are preserved in the Natural History Museum, London (Kimmins, 1949).

Material: Pai River Game Reserve, Plateau State, 1350 m, 1 ô, 4 o + , 11.IV.1978; Kano City, Kano State, at light, 1 , , 14.X.1978.

Ascalaphus lloydi (Kimmins, 1949)

This species, described as Helicomitus lloydi, is known from a single male collected in Azare, Bauchi State, in July 1924. Prost (2013) examined the specimen and confirmed the validity of the species. The holotype is in the Natural History Museum, London.

Brevibarbis argyroptera (Taschenberg, 1879) - Fig. 2

This is the first record of the genus and species in Nigeria. It is mentioned in the list of Medler (1980) as Su- 
phalomitus argyropterus, but as known from the Côte d'Ivoire and not from Nigeria. The species, described from Gabon, inhabits the forest and humid savannahs such as those of Liberia and Côte d'Ivoire in West Africa. The following specimen is the first recorded from a Sudan savannah area.

Material: Panyam, Plateau State, 1 ㅇ, 13.III.1978.

\section{Suhpalacsini}

Disparomitus bacillus (Gerstaecker, 1885)

The species, described from Cameroon, is present from the Congo River Basin to Sierra Leone in West Africa. It seems to be a forest species that extends occasionally to savannah areas. Medler (1980) mentioned its presence in Nigeria. Michel (2019) examined material of $D$. bacillus from three localities in Nigeria: Ibadan (Oyo State in Southwestern Nigeria), Ana (Ana River in Benue State or Ikot Ana in Cross River State, both in Southeastern Nigeria), and Batati (Niger State in Western Nigeria). He noted that "the most northern collection locality, in the Northeast of Nigeria, is located near the 500 millimeter rainfall isohyet (Fig. 139)". The position on the distribution map (Michel, 2019: Fig. 139) corresponds to Borno State. Michel did not, however, provide a published reference nor any indication that he examined related material.

\section{Disparomitus caviceps Michel, 2019}

The holotype was collected in Azare, Bauchi State, by Lloyd in 1925. No other specimen has been recorded from Nigeria (Michel, 2019). The species is known only from Burkina Faso and Nigeria.

\section{Disparomitus lineatus Michel, 2019}

The description of the new species mentioned a male from Nigeria without locality in the collection of the Zoological Museum, Copenhagen University, Denmark, collected in 1958 (Michel, 2019). The additional specimen mentioned below comes from the study area.

Material: Jos, Plateau State, 1 đ̧, 9.IV.1975, leg. D. Baldry, coll. Prost.
Stephanolasca rufopicta (Walker, 1853)

This is a widespread West African species, recorded from Senegal to Nigeria. Medler (1980) and Whittington (2002) included it in their lists for Nigeria.

Material: Samaru, near Zaria, Kaduna State, J. Deeming's house, 1 ふै, 17.X.1978.

Encyoposini

Encyoposis lloydi Esben-Petersen, 1927

The only known specimens of this species are three males and two females of the type series from Azare, Bauchi State, collected by Lloyd in 1926 and preserved in the Natural History Museum, London (EsbenPetersen, 1927). Additional citations in the literature were not supported by new specimens and caused confusion. Medler listed two species: Encyoposis lloydi Esben-Petersen, 1927, and Helicomitus lloydi Kimmins, 1949 (Medler, 1980). In an earlier publication by the first author, Encyoposis lloydi (with author Kimmins) was misunderstood to be Helicomitus lloydi (Kimmins) (Prost, 2013).

\section{Phalascusa pardalis (Gerstaecker, 1888)}

Henwood (1977: Fig. 3) recorded one specimen from Toro, Bauchi State, 17.X.1973. It is a fairly frequent species in West Africa, recorded from Senegal, The Gambia, Guinea, Sierra Leone (Tjeder, 1980), Mali and Burkina Faso (Michel \& Akoudjin, 2013), Nigeria, and east of West Africa from the Central African Republic, northeastern part of Democratic Republic of the Congo, and Northern Uganda (Tjeder, 1980).

Material: Jos, Plateau State, 1 Oૈ, 1.XI.1978; Samaru, near Zaria, Kaduna State, J. Deeming's house, 1 ô, 17.X.1978.

\section{PALPARIDAE}

Lachlathetes furfuraceus (Rambur, 1842)

Palpares equestris Navás, 1912 was described from Zungeno in "Norte de Nigricia" based on a female in the Natural History Museum, London (Navás, 1912a). The correct name of Zungeno is Zungeru, located in 
Niger State, Northwestern Nigeria, slightly outside our study area. Palpares equestris was synonymised with Palpares furfuraceus by Banks (1913a). The occurrence of Lachlathetes furfuraceus in Nigeria was confirmed by Medler (1980). Whittington (2002) had originally reported Palpares furfuraceus without a locality. The exact location of the material preserved in the National Museums of Scotland from Northeastern Nigeria is Biu, Borno State, 3 우, det. A. Prost and A. Whittington. In actual fact, L. furfuraceus occurs in the entire West Africa. It is a typical species of dry savannah and inhabits regions which receive between 800 and $1100 \mathrm{~mm}$ annual rainfall with a tolerance for more humid environments (Prost, 2010).

\section{Nosa tigris (Dalman, 1823)}

This is the most common species in West African savannahs. Henwood (1977) illustrated 1 male and two females from Toro, Bauchi State. He mentioned that the species is common in Maiduguri, Borno State. In addition, Nosa calceata Navás, 1912, a junior synonym of Nosa tigris, was described from a male specimen collected in 1903 in "Nigritie", a vague entity that corresponded to the interior of Nigeria, and more precisely to all territories north of the Niger and Benue rivers (Navás, 1912b). In the same year, Navás (1912a) reported as $N$. tigris another male from Zungeno (now Zungeru, see earlier) also in "Norte de Nigricia". The synonymy was established by Banks (1913a). Complete information about $N$. tigris and its synonyms was given in the revision of the genus by Prost (2019). Parameres and male ectoprocts according to material from Nigeria were illustrated in the same revision.

Material: Jos, Plateau State, 1 ค, 3.X.1976; 1 ô, 5.X.1978; 3 우, 11-15.X.1978; 1 ㅇ, 9.XI.1978; 45 $\mathrm{km}$ north of Biu, Borno State, 1, , 28.X.1976.

\section{Palparellus spectrum (Rambur, 1842)}

Navás (1912b) designated Palpares spectrum as type species of the newly described genus Palparellus. Shortly afterwards, Banks (1913a) downgraded the genus to a subgenus, and Esben-Petersen (1916) synonymised it with Palpares. It was not until 80 years later that Mansell (1996) reinstated Palparellus as a distinct genus. He came to this conclusion by examining the lectotype of the species and a female from

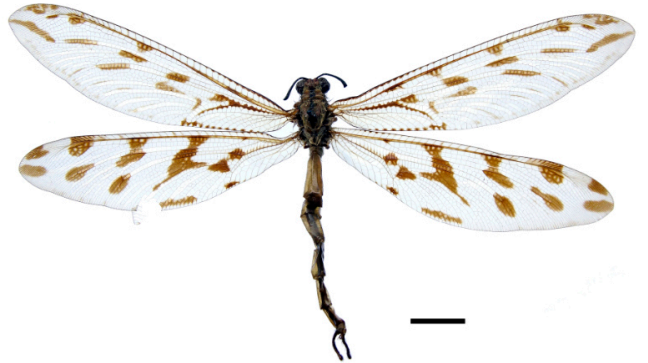

Fig. 3. Palpares incommodus $\widehat{\partial}$ from Sabon Gida, 9.IV.1978. Scale bar: $1 \mathrm{~cm}$.

Samaru, Kaduna State. Although the state of Kaduna is outside our study area, it is located only $58 \mathrm{~km}$ northwest of Jos. P. spectrum is distributed in the whole of West Africa and the Republic of the Congo.

\section{Palpares cephalotes (Klug, 1834)}

Henwood (1977) reported a female from Maiduguri, Borno State, as Palpares cataractae Péringuey, 1910. Revising this record, Prost $(1995,2010)$ concluded on the basis of a photograph published by Henwood (1977: Fig. 8) that there was a misidentification and that the specimen belonged to $P$. cephalotes. The range of $P$. cataractae is restricted to Southern Africa northwards to Angola and Zambia, and does not reach West Africa. P. cataractae, mentioned for Nigeria by Henwood (1977), Medler (1980), and Whittington (2002), should be deleted from the list of Nigerian fauna. $P$. cephalotes is a Middle East and Central Asia species distributed from Afghanistan and Pakistan to Egypt. It is locally reported from Sudan to Senegal in arid zones on the southern edge of the Sahara desert (Prost, 2010), where it is sporadic.

\section{Palpares incommodus (Walker, 1853) - Fig. 3}

This species is often confused with Palpares radiatus Rambur, 1842 from which it can be separated by the examination of male genitalia. P. radiatus lives in drier areas, $P$. incommodus prefers humid environments. Stitz (1912) described Palpares rubescens from Jola, now Yola, on the Benue River, in Adamawa State. Banks (1913a) made it a junior synonym of Palpares incommodus, which is thus present in Northern Nigeria. The exact location of the specimen reported by Whittington (2002) and preserved in the National Mu- 
seums of Scotland is Biu, Borno State, 1 , det. A. Prost and A. Whittington.

Material: Sabon Gida, Pai River Game Reserve, Plateau State, 1 J , 9.IV.1978.

Palpares longimaculatus Akoudjin \& Michel, 2011

This species is recorded for the first time from Nigeria. Henwood (1977: Fig. 9) illustrated a female from Maiduguri, Borno State, as Palpares radiatus Rambur, 1842, which can now be attributed to Palpares longimaculatus, recently described by Akoudjin \& Michel (2011). P. radiatus is a species found in dry savannahs, occurring from Senegal and Mauritania to Chad. It was reported in Nigeria as a result of the erroneous identification by Henwood (1977) and without a reference to an existing specimen by Prost (1995, 2010). P. radiatus should be deleted for the time being from the list of species in Nigeria. Although the species has not been found in Nigeria so far, it is likely to be present and likely to be discovered following more careful investigation. P. longimaculatus was found and described from Senegal and Burkina Faso. Its first recording in Nigeria extends its known range by $1900 \mathrm{~km}$ eastwards.

\section{Palpares nigrescens Navás, 1914 - Fig. 4}

This uncommon species, described by Navás (1914a), is known from no more than a dozen specimens, with a mention from Nigeria in Medler (1980). A specimen in the collection of the National Museums of Scotland was collected in Biu, Borno State, 1 q, published by Prost (2010).

Material: $10 \mathrm{~km}$ east of Kunini, Taraba State, rocky savannah, 1 , , 28.II.1978.

\section{Palpares obsoletus Gerstaecker, 1888}

Navás (1912c) described Palpares longicornis from "Zungeno, nord de Nigritie", now Zungeru. The species was recognised as a synonym of Palpares obsoletus by Esben-Petersen (1916). The presence of the species was confirmed by Henwood when he illustrated a female from Toro, Bauchi State, which he misidentified as Palpares tigris (Henwood, 1977: Fig.5). Whittington (2002) reported this species from Northern Nigeria

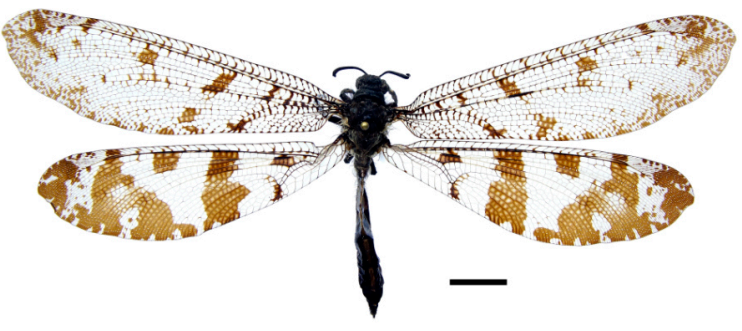

Fig. 4. Palpares nigrescens $q$ from Kunini, 28.II.1978. Scale bar: $1 \mathrm{~cm}$.

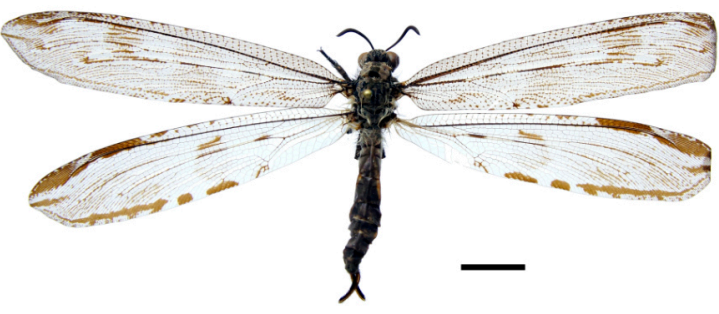

Fig. 5. Stenares arenosus $\widehat{\jmath}$ from Jos, 2.III.1977. Scale bar: 1 $\mathrm{cm}$.

as Palpares longicornis Navás, 1912. There is no recent record of $P$. obsoletus in Nigeria.

Parapalpares latipennis (Rambur, 1842)

Insom and Carfi created the genus Parapalpares and designated P. latipennis as the type species (Insom \& Carfi, 1989). The type locality of its synonym Palpares nigrita, described by Navás (1912b) is situated in Western Nigeria. The occurrence of Parapalpares latipennis in Nigeria was confirmed by Whittington (2002) who reported Palpares latipennis from Nigeria without a locality. The first records in Northeastern Nigeria are due to the identification of this material preserved in the National Museums of Scotland from Yankari, Bauchi State, 1 วิ, 1 + ; Biu, Borno State, 1 ô, 1 क; Maiduguri, Borno State, 1 Õ, 1 q; det. A. Prost and A. Whittington. The genus is revised by Prost (2018). The range of the species covers the whole of West Africa, Chad, and Sudan.

\section{Stenares arenosus Navás, 1924 - Fig. 5}

This species is recorded for the first time from Nigeria. It was known to date from a small area in Southern 
Mali and Southern Burkina Faso (Prost, 2010). The locality where it was found in Nigeria is the easternmost and southernmost, and shifts the known range of the species $1500 \mathrm{~km}$ eastwards.

Material: Jos Wildlife Park, Plateau State, 1350 m, 1 §, 2.III.1977.

Stenares hyaena (Dalman, 1823)

This species was firstly reported for Nigeria by Medler (1980) as Stenares hyena ( (sic). It was published later by Prost (1995) from a locality in the southwestern part of the country. The occurrence in Nigeria was confirmed by Whittington (2002) who reported it without a locality. The exact collection place of the specimen preserved in the National Museums of Scotland with first record in Northeastern Nigeria is Jos Hill, Plateau State, 1 , , det. A. Prost and A. Whittington. The range of the species includes West Africa, Central African Republic, Democratic Republic of the Congo, and Sudan.

\section{Tomatares clavicornis (Latreille, 1829)}

The finding of this species in Nigeria is due to Whittington (2002), who originally reported it without a locality. Among a number of specimens from all over Nigeria preserved in the National Museums of Scotland, one is from Kwaya Tera, Borno State, 19 , det. A. Prost and A. Whittington. T. clavicornis is distributed in West Africa, Chad, and Sudan.

\section{MYRMELEONTIDAE}

\section{Acanthaclisinae}

\section{Centroclisis distincta (Rambur, 1842)}

This is the largest West African Centroclisis. It was unfortunately confused with other species prior to the revision of the West African taxa (Prost, 1999). The revision confirmed the valid identification as $C$. distincta of a female from Lagos in the Natural History Museum, London. The confirmed distribution includes Senegal, Mali, Burkina Faso, Ghana, and Nigeria. Jos is the easternmost locality in the range.

Material: Jos, Plateau State, $1350 \mathrm{~m}, 1$ ㅇ, 15.X.1978.

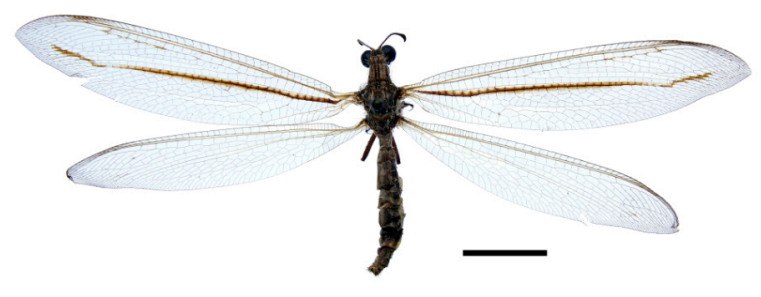

Fig. 6. Centroclisis lineatipennis $\bigcirc$ from Pandam, 1.X.1978. Scale bar: $1 \mathrm{~cm}$.

Centroclisis lineatipennis (Péringuey, 1910) - Fig. 6

This species is recorded for the first time from Nigeria as well as from West Africa. It is a Southern African species distributed from Tanzania to Angola and further north up to Brazzaville in the Republic of the Congo (Prost, 1999). It was not expected to be found in Nigeria. Pandam Wildlife Park is the northernmost and westernmost locality, and expands the known range of the species by $1600 \mathrm{~km}$ to the northwest of Brazzaville, the closest known locality to date. $C$. lineatipennis is a valid species which cannot be reduced to the status of a simple morph of Centroclisis brachygaster (Rambur, 1842) as proposed by Krivokhatsky (2005). C. brachygaster is poorly understood, is probably restricted to the southern part of Africa, and is in need of redefinition.

Material: Pandam Wildlife Park, Plateau State, 1 + , 1.X.1978.

\section{Centroclisis rufescens (Gerstaecker, 1885)}

In his revision of West African Acanthaclisini, Prost (1999) recorded a female from Samaru, Kaduna State, and another female from Minna, Niger State, both deposited in the Natural History Museum, London. Henwood (1977: Fig.16) illustrated a male from Toro, Bauchi State, which he misidentified as $C$. distincta. Further to the 1999 revision, Krivokhatsky (2005) showed that linear darkening along one or several longitudinal veins of the forewing membrane was not a specific discriminant in Acanthaclisinae. He proposed that black striped specimens receive infra-specific status as morphs. He therefore synonymised Centroclisis infernalis, described by Navás (1912d) with Centroclisis rufescens (Gerstaecker, 1885), a proposal that the lack of significant differences in the structure of male genitalia supports. Specimens of Centroclisis 
rufescens in the Sofia Museum collection belong to both morpha typica and morpha infernalis.

Material: Pandam Wildlife Park, Plateau State, at

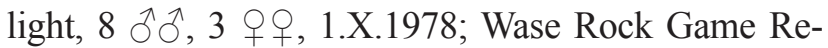
serve, Plateau State, 1 q, 4.IX.1978; 2 qo, 19.IX.1978; Jos, Plateau State, $1350 \mathrm{~m}, 1$ ㅇ, 15.X.1978; Kano City, Kano State, at light, 1 , 16.X.1978; $37 \mathrm{~km}$ west of Maiduguri, Borno State, 6

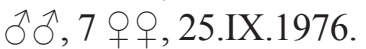

\section{Syngenes debilis (Gerstaecker, 1888)}

This species was described from Lagos in Nigeria. The first record in Northeastern Nigeria was reported by Prost (1999) based on a specimen from Yola, Adamawa State. The species is the single member of the genus Syngenes that occurs in West Africa, from Cape Verde and Senegal to Nigeria (Prost, 1999; Mansell, 2018).

\section{Myrmeleontinae}

Dendroleontini

\section{Genus Bankisus Navás, 1912}

Genus Bankisus is recorded for the first time in Nigeria and in West Africa. To date, Bankisus, described by Navás (1912c), comprised seven species so far, represented by a small number of specimens that are found sporadically. They are always rare. The centre of dispersion of the genus is in the southern half of Africa (Fig. 7). The most widespread species is Bankisus oculatus Navás, 1912, from South Africa to Tanzania (Navás, 1912c; Mansell, 1985; Kemal \& Koçak, 2013), and its synonym Gymnocnemia kristenseni EsbenPetersen, 1915, which was described from Ethiopia. Bankisus carinifrons (Esben-Petersen, 1936) occurs between South Africa and the Democratic Republic of the Congo. Two other species, Bankisus triguttatus Navás, 1926 and Bankisus elegantulus (EsbenPetersen, 1936), also inhabit the Congo River Basin (Democratic Republic of the Congo). Bankisus antiatlasensis Ábrahám, 2009 is recorded in Morocco. Bankisus maculosus Hölzel, 1983 is endemic to the south of the Arabian Peninsula. The last described species of Bankisus is B. sparsus Zhan \& Wang, 2012 from China. Genus Bankisus was considered absent from West Africa (Mansell, 1985). It was therefore a surprise to find two specimens in the Nigerian material, and even more to discover that they belong to a new species that differs significantly from known African taxa. The new species is described below.

Taxonomic notes. Of all eight species of Bankisus, including the new species, only the male is known of $B$. maculosus; for B. sparsus, B. elegantulus, and $B$. triguttatus, only females are known, the latter two species being known only from a single female holotype. Of the other four species, both sexes are described. Genitalia in both sexes of four species are described and illustrated: B. oculatus and B. carinifrons (by Mansell, 1985), B. antiatlasensis (by Ábrahám, 2009), and the new species (presented here). In B. maculosus, only the male genitalia are illustrated (by Hölzel, 1983), and in B. sparsus, only the female genitalia (by Zhan \& Wang, 2012). There is a great difference between the authors in the quality of the description and of the drawings of the genitalia. In Mansell (1985), descriptions are detailed, drawings are precise and many in number (nine for each species), whereas in Hölzel (1983) and Ábrahám (2009), description is lacking or very short, drawings are schematic and few (in three cases, only in lateral view). For example, tergite 9 is omitted by Ábrahám (2009: Fig. 3C).

Mansell (1985) synonymised B. kristensen $i$ with $B$. oculatus due to lack of distinctions in male genitalia and in other characteristics, and only differences in the width of the wings. In fact, the wings of the holotype of $B$. kristenseni are narrower than the wings of every specimen of Bankisus illustrated to date. The markings of the wings are quite different from those of $B$. oculatus and resemble the markings of $B$. maculosus. We think that we cannot exclude the possibility that $B$. kristenseni from Ethiopia is either a distinct species or is conspecific with $B$. maculosus.

Ábrahám (2017) regarded B. sparsus as belonging to an undescribed genus. We agree with the view that this species from Southeastern China (Guangxi Province) does not belong to Bankisus.

Chorological notes. The locality Maboya in former German East Africa of $B$. oculatus is localised by Mansell (1985) in Tanzania. In fact, Maboya is located between Beni and Butembo in North Kivu Province in the Democratic Republic of the Congo near Virunga National Park. The locality is situated $54 \mathrm{~km}$ from the Ugandan border and $190 \mathrm{~km}$ from the border of the former German East Africa, on the territory of which there is no other place of the same name. Therefore, as a result of the revision of the location of this record, 


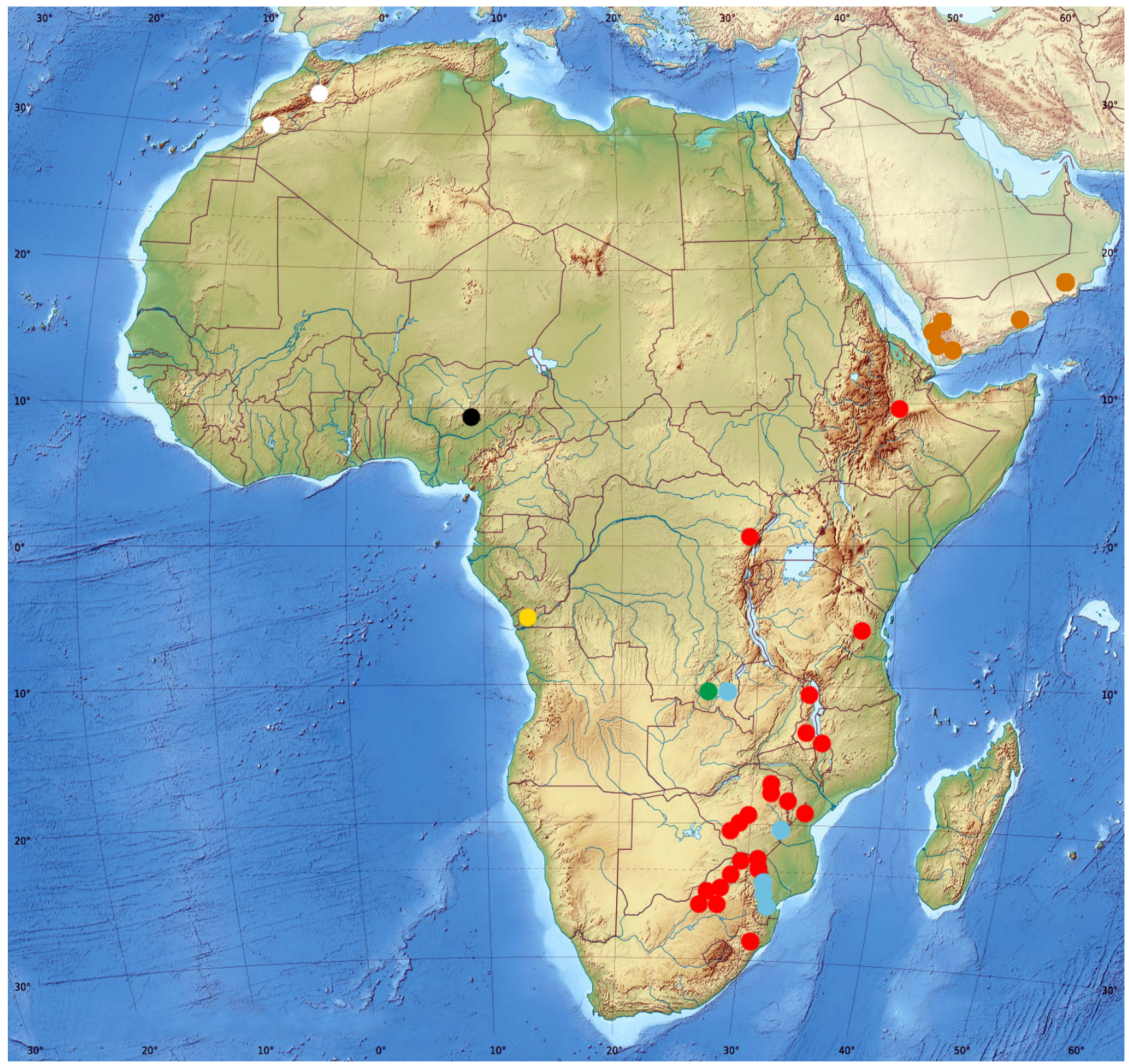

Fig. 7. Distribution of the genus Bankisus. Symbols: red, B. oculatus; blue, B. carinifrons; green, B. elegantulus; yellow, B. triguttatus; black, B. beroni sp. n.; white, B. antiatlasensis; brown, B. maculosus. The exact position of the locality in Ethiopia is unknown. About the occurrence of B. carinifrons in Tanzania and Malawi, and of B. oculatus in Swaziland, not presented on the map, see the text. For the species occurring in Yemen, see the text. B. sparsus from China is not included because it belongs most likely to another genus. (Map outline credit: Eric Gaba, CC-BY-SA-3.0, via Wikimedia Commons).

published by Mansell (1985), B. oculatus is reported here for the first time from the Democratic Republic of the Congo. This increases the number of species of Bankisus in this country to four.

There is confusion about the species of Bankisus which occurs in Yemen. Mansell (1985) identified a female from Sana'a as B. oculatus. Knowing B. macu- losus, he stated that this specimen does not show any differences that separate it from the other specimens of B. oculatus. Hölzel (1998) treated B. maculosus as an Arabian endemic species with a range limited to Yemen and Oman. His information on the occurring of the species in Yemen is based on material from four localities published later by the same author (Hölzel, 
2002). We consider that the female from Sana'a, published by Mansell (1985), does not belong to B. oculatus, thus excluding Yemen from the range of this species. Sana'a is included on Fig. 7 as a locality of $B$. maculosus.

Stange (2004) included "Congo" and "Zaire" in the range of $B$. carinifrons. Under Zaire, he meant the Democratic Republic of the Congo (formerly Belgian Congo or Congo Kinshasa), and under Congo, the Republic of the Congo (formerly French Congo or Congo Brazzaville). For the entire range, Stange (2004) listed Congo, South Africa, Zaire, and Zimbabwe, citing Mansell (1985). The latter, however, mentioned the same countries except Congo. On the other hand, Stange (2004) reported that B. elegantulus and $B$. triguttatus occur only in "Congo", referring to the Democratic Republic of the Congo. Therefore, the Republic of the Congo should be removed from the range of $B$. carinifrons because the mention of Stange (2004) is not supported by either quoting another publication nor from data on a collected specimen. Surprisingly, Stange (2004) omitted South Africa in the distribution of B. oculatus, although he cited Mansell (1985), who listed ten localities in South Africa.

The map of Ábrahám (2009: Fig. 4) on the distribution of Bankisus calls for comments. First, the symbols on the map do not correspond to the exact position of the localities, and only a single locality of a species is marked in each country. Consequently, a precise map was drawn up (Fig. 7). Second, inaccuracies regarding the species' ranges need to be corrected. Ghana is erroneously marked on the map of Ábrahám as a country in which $B$. oculatus occurs, whereas not a single species of Bankisus was ever reported from Ghana, and, in fact, prior to this study, from any part of West Africa. A record of $B$. carinifrons was also inaccurately placed in Zambia by Ábrahám. There is no species of Bankisus published to date from Zambia. Furthermore, the localities of $B$. oculatus and B. carinifrons in Zimbabwe were omitted in the map by Ábrahám. The former species is known from ten localities in Zimbabwe, including the type locality. B. maculosus is misspelled as $B$. maculatus by Hölzel (1998: 135) and Ábrahám (2009: Fig. 4). The revision of Mansell (1985) is erroneously cited twice as published in 1983 by Ábrahám (2009: 423).

There are a few more mentions of species of Bankisus from other countries. Whittington (2002) reported B. carinifrons from Tanzania. In the South African Animal Checklist of the South African Na-

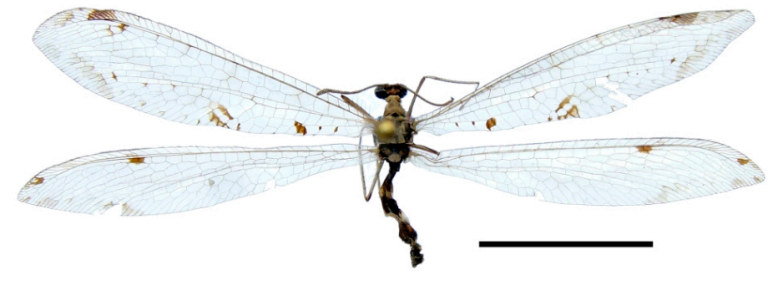

Fig. 8. Bankisus beroni sp. n., paratype $q$ from Jos, October 1976. Scale bar: $1 \mathrm{~cm}$.

tional Biodiversity Institute (http://biodiversityadvisor.sanbi.org/research-and-modelling/checklistsand-encyclopaedia-of-life/south-african-animalchecklist/ [ ; accessed on 10 May 2019), two species of Bankisus are listed among Neuroptera compiled by Mervyn Mansell. According to the website, B. oculatus is distributed also in Swaziland (now Eswatini), and $B$. carinifrons occurs also in Malawi; two countries from which these species have not been documented in the published literature. We accept this information as credible based on collected specimens from the countries mentioned, but we do not include the data on the map (Fig. 7) because the exact localities are not known.

\section{Bankisus beroni Prost \& Popov sp. n. - Figs 8-16}

Type material. Holotype: $\widehat{\jmath}$, Nigeria, Jos, Plateau State, $9^{\circ} 56^{\prime} \mathrm{N}, 8^{\circ} 53^{\prime} \mathrm{E}$, alt. $1300 \mathrm{~m}$, 5.II.1977, leg. Petar Beron. Paratype (Fig. 8): 1 q, Nigeria, Jos, Plateau State, October 1976, leg. Petar Beron. Holotype and paratype are deposited in the National Museum of Natural History, Sofia, Bulgaria.

Description. Male and female are similar with no apparent sexual dimorphism, although the male is of smaller size. The preservation in alcohol may have altered the natural colours and markings of the body.

Measurements. Length of body (in alcohol): 014 $\mathrm{mm}$, $917 \mathrm{~mm}$, shorter after desiccation; length of forewing: $\widehat{o} 17 \mathrm{~mm},+20 \mathrm{~mm}$; length of hindwing $\widehat{\sigma}$ $17 \mathrm{~mm}$, q $20 \mathrm{~mm}$.

Head. Frons uniformly yellowish. Mandibles yellow with brown inner margin. Palps entirely yellow including apical segments. Vertex raised, brownish, with a large transverse dark brown band above the antennal sockets and with a deep longitudinal middle furrow. Antennae short, less than a quarter of the forewing length, comprising 26-28 flagellomeres, moderately 

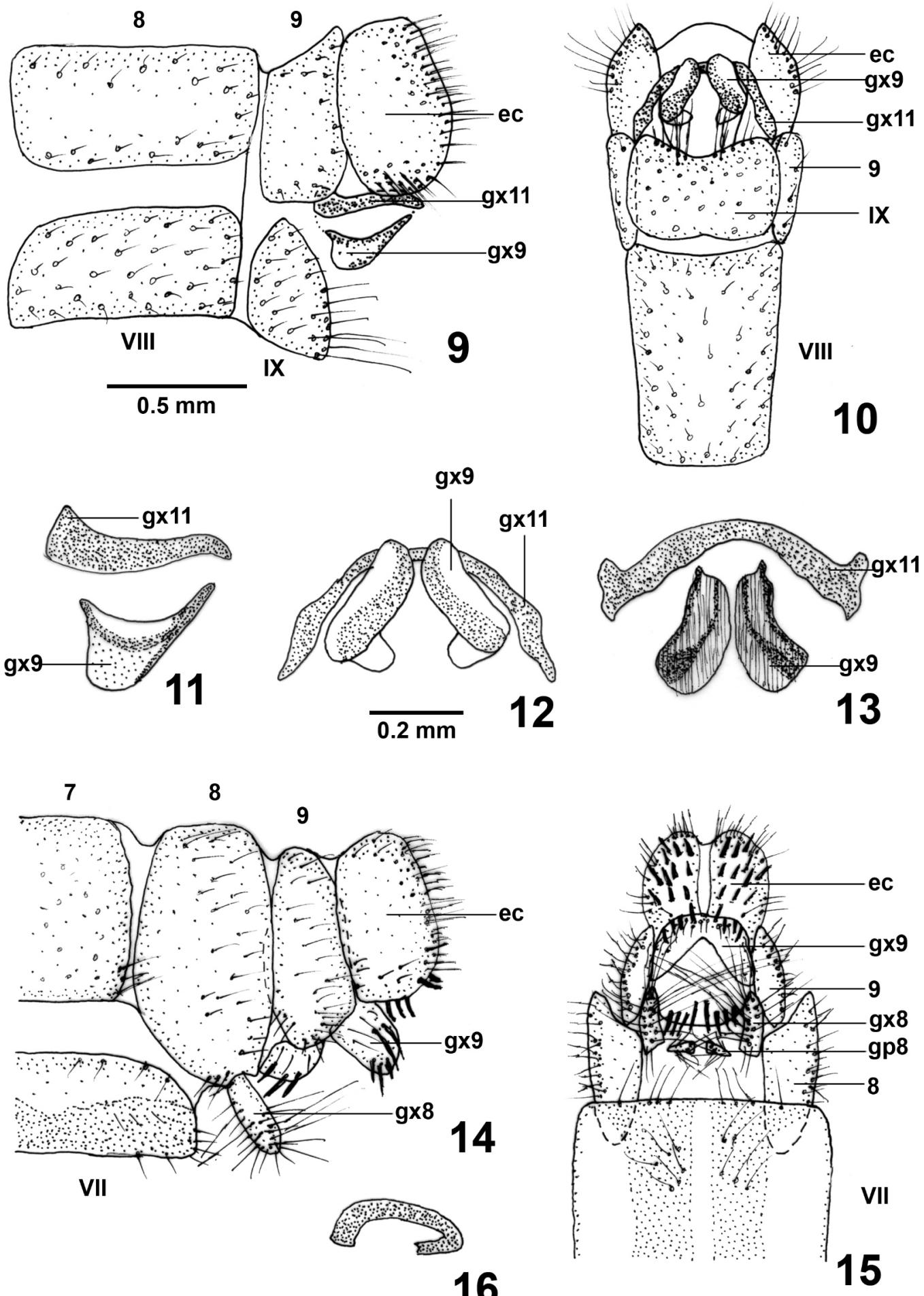

Figs 9-16. Bankisus beroni sp. n.: (9) holotype $\hat{\jmath}$, apex of the abdomen, lateral view; (10) holotype $\hat{\sigma}$, apex of the abdomen, ventral; (11) holotype $\hat{\partial}$, complex of gonocoxites $9+$ gonocoxites 11 , lateral; (12) holotype $\hat{\jmath}$, same, ventral; (13) holotype $\hat{\partial}$, same, caudal; (14) paratype + , apex of the abdomen, lateral; (15) paratype + , apex of the abdomen, ventral; (16) paratype $q$, spermatheca, lateral. Abbreviations: ec, ectoproct; gp8, gonapophysis 8; gx8, gonocoxite 8; gx9, gonocoxite 9; gx11, gonocoxite 11 ; 7, tergite 7; 8, tergite 8; 9, tergite 9; VII, sternite 7; VIII, sternite 8; IX, sternite 9. Scale bars: 0.5 mm (figs 9-10, 14-15); $0.2 \mathrm{~mm}$ (figs 11-13, 16). 
clavate, densely setose, uniformly pale yellow including tips.

Pronotum yellow, with no evident brown markings. A deep transverse furrow, interrupted centrally, separates the anterior third of the pronotum from a trapezoidal posterior part. Margins with long white bristles, 2-4 of them dark along the posterior margin. Meso- and metanotum yellow with long white bristles. Pro-, meso- and metasternum dark brown.

Legs long and slender, yellow, with long and short white and dark setae. Femora yellow with brown longitudinal lines: fore femur with two complete and an incomplete line; middle femur with two complete lines; hind femur with incomplete lines. Tibiae yellow with two brown longitudinal lines (fore and middle tibiae) or without lines (hind tibia). Fore femur with very long white bristles, long black bristles, and short brown hairs. Fore tibia with only $1-2$ very long white bristles and many short dark and pale hairs. Middle femur and middle tibia with the same chaetotaxy as the fore femur. Hind femur and hind tibia with long black bristles and short dark and pale hairs. Tarsomeres brown, with a brush of dark setae on the inferior face of the fifth tarsomere.

Forewing broad with acute apex, not falcate. The venation is the same as for all species of this genus, with three radial crossveins before the origin of Rs. The membrane is hyaline, with speckled brown markings, the larger sitting below the pterostigma, in the cubital field close to the posterior margin, and along anal veins.

Hindwing narrow, pointed. Pterostigma pale, almost unnoticeable. A large brown mark covers the origin of the fifth radial sector vein. There are several darker and lighter dots on the apical and subapical margins.

Abdomen shorter than hindwing. First and second segments dark brown, other segments banded with pale rings. Tergites and sternites covered with a short pale pubescence.

Male genitalia (Figs 9-13). Tergite 9 in lateral view slightly higher than tergite 8 . Sternite 9 short, with a slight median incision on the posterior margin. Ectoprocts with a rounded ventral margin, without projecting posterior end. Components of the complex of gonocoxites $9+$ gonocoxites 11 joined with a membrane. Gonocoxite 11 arcuate, sclerotised, pigmented, narrower in its median part, wider in its lateral parts; at each end with an extension directed dorsally. Mediuncus absent. Gonocoxites 9 short, sclerotised, darkly pigmented at their dorsal and ventral margins, closely situated in their distal parts and very distant in their proximal parts, with a proximal end curved inward and densely spaced parallel striae in the ventral area, more visible in caudal view. Sternite 9 with about ten long black bristles on each side of the posterior margin, the middle ones being the longest. Ectoprocts densely covered with long black setae in their caudal and ventral parts; the longest setae concentrated in the ventral area and ventrocaudal corner.

Female genitalia (Figs 14-16). Tergite 8 tapered posteroventrally at the base of gonocoxite 8 . Tergite 9 in lateral view elongately oval. Ectoprocts almost rectangular. Gonapophysis 7 not visible. Gonapophyses 8 minuscule, triangular. Gonocoxites 8 finger-like; narrow and long. Gonocoxites 9 contact each other forming a hemisphere. There is an unpaired plate-like structure between gonocoxites 8 and gonocoxites 9 . Spermatheca C-shaped, sclerotised, darkly pigmented. Ectoprocts with long brown and black setae in the caudal part, and short, stout, dark brown digging setae, those are straight with slightly curved dorsally end parts. Gonapophyses 8 with straight setae. Gonocoxites 8 with dense, very long, thin setae in the dorsal apical part, and scarce, long, thicker setae in the ventral apical part. Gonocoxites 9 with short, stout, downward directed and slightly curved forwards, dark digging setae in the distal part, and thin setae in the rest. The plate-like structure with short, stout, proximally directed and slightly curved upwards brown digging setae.

Comparison notes. The general aspect of Bankisus beroni sp. $\mathbf{n}$. is similar to that of Bankisus antiatlasensis, especially when considering the markings of the wings which differ significantly from other known species. The major distinguishing characteristics between the two species are given in Table 1. The main difference is in the pronotum. Its front third is divided from the rest with a deep furrow in the new species, and in $B$. antiatlasensis pronotum is not divided (Ábrahám, 2009: Fig. 2). In male genital structures, the difference is in the form of gonocoxites 9 (Fig. 13 in the present paper in contrast to Ábrahám, 2009: Fig. 3B). The big difference between the dimensions of the wings in males and females of $B$. antiatlasensis is noticeable: male forewing $15 \mathrm{~mm}$ long, $4 \mathrm{~mm}$ wide; male hindwing $14 \mathrm{~mm}$ long, $3 \mathrm{~mm}$ wide; female forewings 29-30 mm long, $7 \mathrm{~mm}$ wide; female hindwings 27-28 $\mathrm{mm}$ long, $6.5 \mathrm{~mm}$ wide. Coloration of the pronotum distinguishes $B$. beroni sp. n. (yellow without dark spots) from the other species in the genus: $B$. trigut- 
André Prost, Alexi Popov

Table 1. Comparison of Bankisus beroni sp. n. and Bankisus antiatlasensis.

\begin{tabular}{|c|c|c|}
\hline & Bankisus beroni sp. $\mathrm{n}$. & Bankisus antiatlasensis \\
\hline Pronotum & with deep transverse furrow & without deep transverse furrow \\
\hline Tip of the antennal club & pale yellow & dark brown \\
\hline Apical segment of maxillary palp & yellow & brownish \\
\hline Apical segment of labial palp & yellow & brownish \\
\hline Mediuncus & absent & present \\
\hline Parameres (in caudal view) & short and stout & long and slender \\
\hline 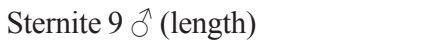 & less than half the length of sternite 8 & more than half the length of sternite 8 \\
\hline Sternite $7 q$ (hind margin) & with rounded posterodorsal part & straight \\
\hline Sternite 7 ㅇ & $\begin{array}{l}\text { prolonged; ends distally beyond the level of } \\
\text { tergite } 7\end{array}$ & $\begin{array}{l}\text { not prolonged; ends distally at the level of } \\
\text { tergite } 7\end{array}$ \\
\hline
\end{tabular}

Table 2. Comparison of the terms for male and female genital sclerites used in Myrmeleontidae.

\begin{tabular}{|lllll|}
\hline $\begin{array}{l}\text { Genital sclerites after } \\
\text { Aspöck \& Aspöck } \\
\text { (2008) }\end{array}$ & Tjeder (1954) & Mansell (1985) & Stange (1994) & Wang et al. (2012) \\
\hline Male & & & & parameres \\
\hline gonocoxites 9 & parameres & parameres & parameres & mediuncus \\
\hline- & mediuncus & mediuncus & mediuncus & gonarcus \\
\hline gonocoxites 11 & gonarcus & gonarcus & gonarcus & pregenital plate \\
\hline Female & & pregenital plate & pregenital plate & 8th interior \\
\hline gonapophyses 7 & praegenitale & posterior gonapophyses & anterior gonapophyses \\
\hline gonapophyses 8 & - & & & $\begin{array}{l}\text { 8th external } \\
\text { gonapophyses }\end{array}$ \\
\hline gonocoxites 8 & gonapophyses anteriores & anterior gonapophyses & posterior gonapophyses & $\begin{array}{l}\text { 9th interior } \\
\text { gonapophyses }\end{array}$ \\
\hline gonocoxites 9 & gonapophyses laterales & lateral gonapophyses & lateral gonapophyses & \\
\hline
\end{tabular}

tatus (brown), B. elegantulus (dark reddish brown), $B$. maculosus (pale brown pronotum; similar markings on the wings), B. oculatus (whitish with two broad blackish marks), B. carinifrons (whitish with two dark spots), B. sparsus (yellowish pronotum as in the new species but with many small spots on the forewing versus few spots and shadings in B. beroni sp. n.). The main distinguishing characteristic in the male genitalia is the length of sternite 9. It is as long as one third of the length of sternite 8 in B. beroni sp. n. (Fig. 9) and more than half the length of sternite 8 in the other four species with described male genitalia. Another characteristic of the new species is the median caudal incision of sternite 9 in the males (Fig. 10).

Bankisus antiatlasensis, the most closely related to the new species, is endemic to Morocco. It is known from Anezol in Anti-Atlas Range in Southern Morocco (Ábrahám, 2009, 2017) and Missour in the high plateau 
east of Middle Atlas Range in Eastern Morocco (Michel \& François, 2019). Both localities are $2850 \mathrm{~km}$ distant from Jos in Nigeria and separated by the Sahara Desert, making it ecologically irrelevant to consider a possible identity. The closest locality of the genus Bankisus to the Nigerian one, however, is Tshela, the type locality of Bankisus triguttatus in the Democratic Republic of the Congo, situated $1700 \mathrm{~km}$ south of Jos.

Etymology. Named after Dr Petar Beron, collector of the new species.

Terminology notes. Tjeder (1954) is the first who introduced order in the chaos of numerous terms of the genital structures in Neuroptera and proposed many new neutral (non-homologous) names for them by comparing the figured representatives of different families. An important step forward in terminology is the homology of male and female genital structures proposed by Aspöck \& Aspöck (2008) based on the genital structures of primitive insects (Machilidae). This scheme is used in the present paper. A comparison of the genital terms in Myrmeleontidae is presented in Table 2.

\section{Cymothales cybele Mansell, 1987}

The only known specimen of this species is the female holotype from Vom, Plateau State, collected in 1960, preserved in the Natural History Museum, London.

Cymothales liberiensis Van der Weele, 1904

Henwood (1977: Fig.11) illustrated one specimen from Toro, Bauchi State.

\section{Cymothales mirabilis Gerstaecker, 1894}

Henwood (1977: Fig.10) recorded a female from Toro, Bauchi State. He commented that it is a fairly common species in the area.

Nemoleontini

Banyutus hesione (Banks, 1911) - Fig. 17

Henwood (1977: Fig.13) reported this species from Toro, Bauchi State, under the name Formicaleo lynx,

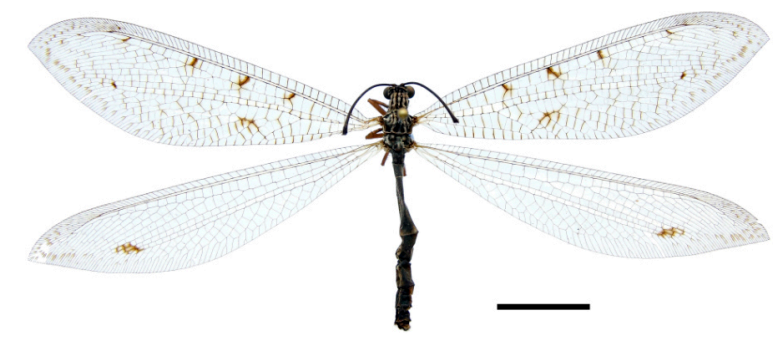

Fig. 17. Banyutus hesione $q$ from Jos, 19.X.1978. Scale bar: $1 \mathrm{~cm}$.

following Navás (1912a) who described Formicaleo lynx from "Nigricia". Its presence in Nigeria is mentioned by Medler (1980) as two species under the names Nemoleon hesione and Formicaleon lynx, and by Whittington (2002) as Distoleon lynx. The correct denomination is Banyutus hesione (Banks, 1911). In 1913, Banks established that Formicaleo lynx Navás, 1912 was similar to the species he had described in 1911 as Formicaleon hesione and made it a junior synonym (Banks, 1913b). Authors generally ignored Banks' second publication, until Stange (2004) confirmed the synonymy and transferred the species into the genus Banyutus.

Material: Jos, Plateau State, $1350 \mathrm{~m}, 1$ q, 18.VI.1977; 1 ઈิ, 2 우, 28.IX.1978; 1 ઈ, 3 우우,

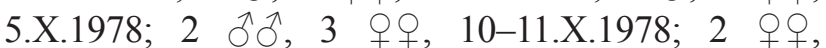
15.X.1978; 2 ㅇ, , 19-20.X.1978; 1 + , 30.X.1978; 1 ㅇ, 9.XI.1978; Wase Rock Game Reserve, Plateau State, 1 ô, 19.IX.1978; Pandam Wildlife Park, Plateau State, 2

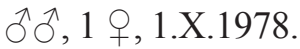

\section{Genus Capicua Navás, 1921}

This is a new genus for the fauna of Nigeria. Michel \& Akoudjin (2011) revisited the genus Capicua, challenged the synonymy with genus Geyria proposed by Stange (2004), ascertained its validity, and described two new species, both from Mali and Burkina Faso. Both are reported here from Northern Nigeria. The genus consists of three species: the two species mentioned below and Capicua fulvicauda Navás, 1921, the type species of the genus, from Chad. It is noteworthy that Capicua nigra and Capicua acalcarata were found in the same localities, and sometimes on the same date, in Mali and Burkina Faso, and subsequently in Nigeria. Pandam is the easternmost and southern- 
most locality of both species and their finding there extends their known ranges by $1400 \mathrm{~km}$ to the east of Forest of the Mou in Burkina Faso.

Capicua acalcarata Michel \& Akoudjin, 2011

First record for Nigeria.

Material: Pandam Wildlife Park, Plateau State, 1 q, 15.II.1977.

Capicua nigra Michel \& Akoudjin, 2011

First record for Nigeria.

Material: Pandam Wildlife Park, Plateau State, 2 우, 15. II.1977.

\section{Genus Creoleon Tillyard, 1918}

This is a genus with high species diversity. It contains 48 species, of which 35 are found in Africa and in Madagascar (Oswald, 2018). Although the species of Palaearctic origin are slightly more numerous than those of Afrotropical origin, the center of dispersion of the genus is most likely the Afrotropic, because the range of the genus covers the entire Afrotropical Region and only the southern half of the Palaearctic. The genus is in need of revision. The genitalia have not yet been studied in African species, and thus cannot be compared for identification purpose. Four to six species are present in West Africa according to published records. Species such as Creoleon africanus (Rambur, 1842)

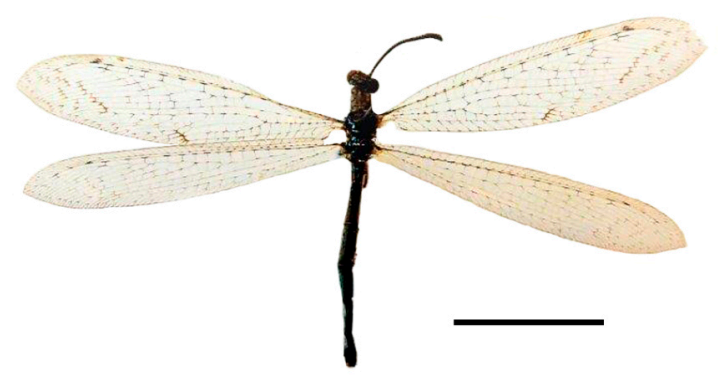

Fig. 18. Creoleon nigrithorax sp. n., holotype $\widehat{\overbrace{}}$ from Burkina Faso, Bodadiougou, 18.XI.1977. Scale bar: $1 \mathrm{~cm}$. and Creoleon nubifer (Kolbe, 1897), large and mostly pale, are easily identifiable. The smaller grey and black specimens have been attributed to Creoleon mortifer (Walker, 1853), a questionable decision since it is principally a Southern African species. Their identity has yet to be determined.

The material brought by P. Beron contains a Creoleon which differs from $C$. mortifer on two points: wings are not falcate, their posterior margin lacks the concavity below the tip; the colour pattern of the prothorax differs from all West African taxa, with four pale lines from the angles of the pronotum towards its centre, a characteristic it shares with Creoleon decussatus (Navás, 1914) only, a species described and recorded exclusively from Kenya (Navás, 1914b). A male specimen collected by the first author in Burkina Faso is conspecific with the specimen of P. Beron. We consider it a new species, as described below.

\section{Creoleon nigrithorax Prost sp. n. - Fig. 18}

Type material. Holotype: $\widehat{O}$, Burkina Faso, Bodadiougou, forest gallery, River Comoe, Banfora administrative circonscription, $10^{\circ} 40^{\prime} \mathrm{N}, 4^{\circ} 52^{\prime} \mathrm{W}, 18 . \mathrm{XI} .1977$, leg. André Prost. Paratype: 1 + , Nigeria, Kano City, $12^{\circ} 00^{\prime} \mathrm{N}, 8^{\circ} 35^{\prime} \mathrm{E}, 14 . X .1978$, leg. Petar Beron. Holotype is in the collection of A. Prost, France; it will be deposited in the National Museum of Natural History, Paris. Paratype is in the National Museum of Natural History, Sofia, Bulgaria.

Description. Measurements. Length of body: $\widehat{\partial} 20$ $\mathrm{mm}$, $911 \mathrm{~mm}$ (probably shorter than in vivo because of the desiccation process); length of forewing: 23

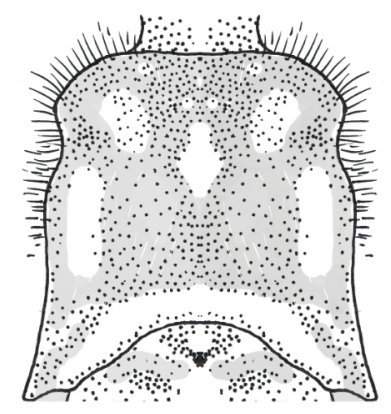

Fig. 19. Creoleon nigrithorax sp. n., pronotum of the holotype. Drawing by Assen Ignatov. 
$\mathrm{mm}$, \& $20 \mathrm{~mm}$; length of hindwing: ô $22 \mathrm{~mm}$, q 19 $\mathrm{mm}$.

Head. Frons and palps yellow. Frons marked with a shining black inverted $\mathrm{V}$ below and between antennae. Occiput and vertex dark grey with two rows of shining black spots. Antennae short, $6 \mathrm{~mm}$ long in ô, $4 \mathrm{~mm}$ long in 9 , distinctly clavate; all flagellomeres with brown annulations from the first segment to the tip; antennal tubercles yellow. Short white hairs on the clypeus and frons.

Pronotum (Fig. 19) dark grey. Anterior transverse furrow marked with two lateral darker pits, and posterior part of pronotum with two shallow darker pits close to the hind angles. A narrow longitudinal yellow stripe marks the middle of the pronotum. It does not reach the anterior margin and is enlarged when reaching the anterior transverse furrow. On each side a yellow marking joins the anterior and posterior dark pits. It is well marked around the pits, more or less indistinct between them, giving the impression that the dark pronotum is marked with four yellow oblique lines originating in its angles. Meso- and metanotum dark grey.

Legs yellow with multiple brown dots. Fore femur thickened, brownish laterally. Hind femur with a brown dorsal line. Tibiae with a brown ring at the distal end. Tibial spurs longer than the first two tarsomeres. Tarsomeres yellow, each with a brown distal ring. Fore femur covered with a thick coating of short white hairs. Middle femur with a mixture of short and long white setae. Hind femur with some short white hair and black spines arranged in two rows underside. All tibiae have short white hairs mixed with longer black setae.

Forewing longer than hindwing; both with an acute tip; their posterior margin evenly rounded. Longitudinal veins pale, with a black spot at each crossvein, and their extremity black when divided to merge with the posterior margin, giving the wings a mottled aspect. Two rows of transversal veins in the apical field are black, as well as transversal veins at the termination of cubitus posterior. Pterostigma pale, almost indistinct, underlined by darkened veins internally. Membrane of all wings unmarked and always transparent.

Abdomen entirely dark, with a short white pubescence on tergites and sternites. Eighth segment laterally marked with yellow. Ninth segment yellow with dark bristles.

Since the study of male genitalia has not been undertaken yet for any of the African species of Creoleon, their examination in this specimen could not provide comparative features that could be used for species dif- ferentiation. It seemed to be a prudent approach to keep the genitalia of this specimen intact for further study.

Diagnosis. Creoleon nigrithorax $\mathbf{s p .} \mathbf{n}$. belongs to a group of small dark species with mottled wings. It differs from all other species by the wings not falcate and by a dark prothorax with four oblique yellow lines organised as a quincunx.

Etymology. The species is named nigrithorax, because its thorax is black.

\section{Creoleon africanus (Rambur, 1842)}

Henwood (1977: Fig. 15) illustrated one specimen from Toro, Bauchi State. This is a species occurring widely in the entire Afrotropical and Palaearctic Africa.

\section{Distoleon diversus (Navás, 1912)}

Henwood (1977: Fig.14) provided a photograph of one specimen of Formicaleon lituratus from Toro, Bauchi State. Formicaleo lituratus Navás, 1912 and Formicaleo diversus Navás, 1912 were described in the same paper (Navás, 1912a), both from Abyssinia (now Ethiopia). F. diversus was transferred to the genus Distoleon by Stange (2004). The two species were published as identical by Banks (1913b). In the paper of Navás (1912a), the name F. lituratus is brought into use on p. 61, and $F$. diversus, on p. 62. In this case, however, the name published on the previous page does not take precedence. The Principle of Priority applies only when a name has been published before another by date (Article 23 of ICZN). When publishing on the same date, the Principle of the First Reviser applies (Article 24.2.2 of ICZN). The First Reviser was Banks (1913b), who announced the identity of the two species. He wrote: Formicaleo lituratus is Formicaleo diversus (p. 152), i.e. he chose the name $F$. diversus. In addition, in the same paper, Banks labelled Fig. 16 (p. 157 ) as Formicaleon (sic) diversus, i.e. he used this name only. Therefore, according to ICZN, the current name of the species should be Distoleon diversus. This species is distributed mainly in East Africa. It occurs in Ethiopia (Navás, 1912a, as Formicaleo diversus and Formicaleo lituratus), Madagascar, Comoros, and Zanzibar (Handschin, 1963, as Creoleon literatus [sic]), and Nigeria. Toro is the only locality in West Africa, a long distance from Ethiopia, the closest country in the species range. Henwood (1977) mentioned 
that there has been some difficulty in identifying the specimen from Toro and that Mr P. C. Barnard of the Natural History Museum, London, was of the opinion it is Formicaleon lituratus.

\section{Distoleon harpalyce (Banks, 1911)}

Henwood (1977: Fig. 12) provided a photograph of a female under the name Formicaleo sanguinolentus from Toro, Bauchi State. The presence of this species in Nigeria is mentioned by Medler (1980) as Formicaleon sanguinolentis (sic) and by Whittington (2002) as Distoleon sanguinolentus. Formicaleo sanguinolentus was described by Navás (1912a). The synonymy Distoleon harpalyce $($ Banks, 1911) $=$ Distoleon sanguinolentus (Navás, 1912) was established by Stange (2004). This species ranks second in terms of frequency in the Sofia material with 49 specimens.

Material: Jos, Plateau State, $1350 \mathrm{~m}, 3$ ถึ่े,

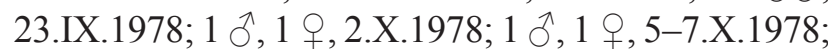

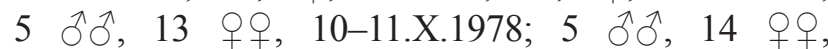
15.X.1978; 1 ô, 2 우, 19.X.1978; 1 ㅇ, 27.X.1978; 1 ㅇ, 9.XII.1978.

\section{Distoleon pullus (Navás, 1940)}

First record for Nigeria. Described from the present Republic of Mali as Formicaleo pullus, it has not been reported since. The first author collected a specimen in Burkina Faso which is mentioned here for the first time. Thus Sabon Gida is the easternmost and southernmost locality, $2050 \mathrm{~km}$ to the east of the type locality. Stange (2004) transferred it to genus Distoleon.

Material: Sabon Gida, Pai River Game Reserve, Plateau State, 1 q, 3.III.1978.

\section{Distoleon tholloni (Navás, 1914)}

First record for Nigeria. The specimen from Nigeria corresponds to Distoleon languidus (Navás, 1931), described as Feina languida from the Democratic Republic of the Congo (Katanga). Recently, this species was placed in synonymy with Distoleon tholloni by Ábrahám \& Giacomino (2020) without evidence and explanation, but only on the basis of apparent similarity. In view of the stability of the nomenclature, we follow the synonymisation and consider it possible. However, as Ábrahám and Giacomino do not compare any morphological structures of $D$. tholloni and $D$. languidus, we believe that this synonymy requires further supporting evidence. The type locality of $D$. tholloni is not known. The species was described from "Congo" (Navás, 1914c), based on a specimen that was collected in 1886, at a time when the name Congo applied to what is now Gabon and beyond it to the Congo River. This uncommon species is reported so far under its name or its synonyms from Mali (Michel \& Akoudjin, 2013, sub Distoleon languidus), Côte d'Ivoire (Navás, 1923, sub Formicaleo tholloni), and Democratic Republic of the Congo (Navás, 1931, sub Feina languida; Navás, 1932, sub Dolicholeon ghesquierinus Navás, 1932).

Material: Jos, Plateau State, 1 ô, February 1978.

\section{Ganguilus pallescens Navás, 1912}

Navás (1912a) described the genus Ganguilus and its type species Ganguilus pallescens from Zungeno in "Norte de Nigricia", now Zungeru, in Niger State. Michel \& Mansell (2010) reported a male of this species from Samaru in Kaduna State. Although the states of Niger and Kaduna are slightly outside the study area of the present paper, Samaru is located only $58 \mathrm{~km}$ northwest of Jos. G. pallescens is a widely distributed species. Its range covers the entire West and North Africa, Somalia, Arabian Peninsula, and Iran.

\section{Ganguilus rex Michel \& Mansell, 2010}

The original description of the species includes a female from "Zaria, Samaru", a locality in Kaduna State, deposited in the Natural History Museum, London, with a label "Barreja imperator (nomen nudum)". The name Barreja imperator was used for the species described as Nelees imperator by Navás (1914a) and transferred to Ganguilus by Michel \& Mansell (2010). Medler (1980) reported "Neleoma sp. nr. imperator Navás, 1913” from Nigeria. Whittington (2002) published Hagenomyia imperator also from Nigeria. Most likely, the information of Medler and Whittington refers to Ganguilus rex, which was not yet described at that time. So far, G. rex has been found only in Southern Mali and Northern Nigeria. Jos is the easternmost and southernmost locality of the species. 
Material: Jos, Plateau State, $1350 \mathrm{~m}, 1$ q, 25-28.III.1978.

\section{Gymnoleon externus (Navás, 1911)}

First record for Nigeria. Gymnoleon gaillardi Navás, 1912 was described from a unique mutilated specimen (the abdomen was missing) collected in the region of Zinder, between Maradi and Dungars (placed by Navás in "Afrique méridionale"). It was collected in 1910 by a member of the Tilho's mission (Navás, 1912e) in charge of the determination of the border between the territory of Nigeria and the colony of Haut Sénégal Niger, i.e. near the present border between Niger and Nigeria. Dungars is very likely identical to Dungass or Dengas, a village in Magaria Department, Zinder Region, Niger, $13^{\circ} 04^{\prime} \mathrm{N}, 9^{\circ} 20^{\prime} \mathrm{E}$, located $90 \mathrm{~km}$ southeast of Zinder. Although close to the border with Nigeria, the location is definitely in the Republic of Niger. The holotype remains the sole name-bearing specimen of G. gaillardi. Based on superficial examination, Banks (1913b) considered it (as G. gaillandi [sic]) a synonym of Gymnoleon exilis Banks, 1911, a species he had just described from Eritrea and Tanzania, and in which he erroneously included two small species that lack tibial spurs in the hind legs, irrespective of their geographical distribution (Banks, 1913b). Synonyms were since reclassified as Neuroleon species: N. nubilatus (Navás, 1912) and $N$. drosimus Navás, 1912.

We consider that the species' identity of the populations in East Africa and in West Africa (Mali and Niger) still needs to be confirmed. With regard to this, the first author examined the only type specimen (holotype) of Gymnoleon gaillardi deposited in the Muséum national d'Histoire naturelle, Paris, which is in poor condition. It is identical with Gymnoleon externus (Navás, 1911) described in a new genus as Mossa externa from Guinea and transferred in Gymnoleon as a new combination by Stange (2004), with which we can consider it to be conspecific. Besides the mentioned countries in West Africa, the species was reported from the Democratic Republic of the Congo under the names of its synonyms Gymnoleon cognatus Navás, 1914 (see Navás, 1914d) and Gymnoleon nubifer Navás, 1936.

Medler (1980) mentions $G$. exilis from Nigeria and this is the first report of the genus Gymnoleon from this country. He probably had in mind the synonymisation of Banks. It is very likely that $G$. exilis from Sikasso in
Southern Mali reported by Michel \& Letourmy (2007) is conspecific with $G$. externus. The female from Sabon Gida fully corresponds to $G$. externus and according to the above-mentioned interpretation of the location of the type locality of $G$. gaillardi is the only specimen of the species from the territory of Nigeria.

In the new combination of Stange (2004) Gymnoleon externa, the gender suffix of the species name does not agree with the generic name. We therefore propose the necessary mandatory change in gender suffix according to Article 34.2 of ICZN from Gymnoleon externa to Gymnoleon externus. Furthermore, we ascertain that Gymnoleon gaillardi Navás, 1912 is not a synonym of Gymnoleon exilis Banks, 1911 and establish a new synonymy: Gymnoleon externus (Navás, 1911) (= Gymnoleon gaillardi Navás, 1912, syn. n.).

Gymnoleon exilis Banks, 1911 stays as a valid name for a species restricted so far to East Africa between Eritrea and Tanzania.

Material: Sabon Gida, Pai River Game Reserve, Plateau State, 1 o, 3.III.1978.

\section{Nemoleon filiformis (Gerstaecker, 1885)}

First record for Nigeria. It is the species illustrated by Henwood as Neuroleon drosimus Navás, 1912 (Henwood, 1977: Fig.17) with two specimens from Toro, Bauchi State. Henwood noted that these specimens probably belong to Neuroleon drosimus according to P. C. Barnard. The length of the abdomen in males is characteristic of Nemoleon filiformis. Neuroleon drosimus is a misidentification. The range of Nemoleon filiformis covers a vast territory in West and Southern Africa from Sierra Leone and Mali to Namibia and Zimbabwe.

Material: Jos, Plateau State, $1350 \mathrm{~m}, 1$ ๙े, 10.X.1976; 1 q, 1.XI.1977; 1 , 11.X.1978; 1 q,

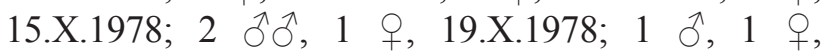
21.X.1978; 2 qo , 27.X.1978; 1 q, 1.XI.1978; 1 ㅇ, 9.XI.1978; Jos Wildlife Park, Plateau State, 1 ô, 1 q, 23.IX.1978; Sabon Gida, Pai River Game Reserve, Plateau State, 1 o, 3.III.1978.

Neuroleon drosimus Navás, 1912

The taxon was described by Navás (1912a) from Nigeria, Badeggi, Niger State, $1 \lesssim$ (Natural History Mu- 
seum, London). Pandam and Kano are located a little east of Badeggi and are the easternmost localities in the range of the species. $N$. drosimus is associated with grass savannah, common in West Africa.

Material: Pandam Wildlife Park, Plateau State, 1 Ô, 1.X.1978; Kano City, Kano State, 1 Jै, 14.X.1978.

\section{Neuroleon modestus (Navás, 1912)}

First record for Nigeria. It had not been mentioned from Nigeria yet, although its presence in this country was very likely. The original description by Navás (1912a) is based on a specimen from Porto-Novo, Benin, a city close to the southwestern border of Nigeria. A strong probability exists that the species listed by Medler (1980) as Neleoma guttatus Navás, 1914 (described by Navás, 1914e) is in fact Neuroleon modestus. The absence of reference material in Medler makes it impossible to determine. Michel \& Akoudjin (2012) reviewed both species; they decided to retain them as separate and valid, because although morphologically similar, the male genitalia differ. Because of the discontinuity of their area of distribution, i.e. West Africa for $N$. modestus, and Namibia to Mozambique for $N$. guttatus, they suggested that these might be vicariant species.

Material: Jos, Plateau State, 3 ふ઼

\section{Neuroleon nubilatus (Navás, 1912)}

The species was described as Klapalekus nubilatus by Navás (1912c) based on a female specimen from "Zungeno, Northern Nigritia", now Zungeru. Whittington (2002) notes that Klapalekus nubilatus from Nigeria is present in the collection of the National Museums of Scotland. N. nubilatus is widely distributed in the dry Sudano-Sahelian area, with confirmed presence in Mali, Burkina Faso, and Sudan. With 83 specimens, $N$. nubilatus is by far the dominant species in the population sampled by P. Beron on Plateau State. Occurrence during the year is restricted to a limited period, about 45 days at the end of the rainy season, from late September to mid-November.

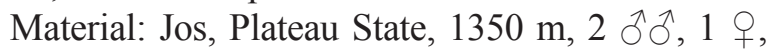

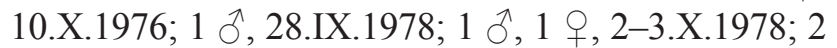

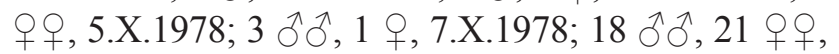

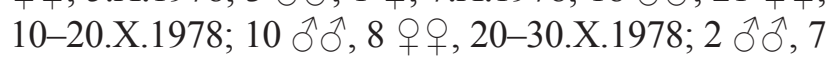
우, 1.XI.1978; 1 ㅇ, 17.XI.1978; Pandam Wildlife
Park, Plateau State, 1 J , 1.X.1978; Vom, Plateau State, 1 ô, 1 क , 7.XI.1977; Samaru, near Zaria, Kaduna State, J. Deeming's house, 1 ô, 17.X.1978.

Neuroleon pardalice (Banks, 1911)

One male from Gadau, Bauchi State, February 1933, is reported from the Natural History Museum, London (Michel \& Akoudjin, 2012).

\section{Neuroleon rapax Michel \& Akoudjin, 2012}

First record for Nigeria. This is a species that was recently isolated from the group of the small Neuroleon. A little larger than $N$. nubilatus, its characteristics are that tarsal claws are capable of closing against distal tarsomeres, with tibial spurs present. Vom and Jos are the southernmost localities in its range, compared to the only known localities in Southern Mali and Northern Cameroon (the type series).

Material: Jos, Plateau State, at light, 1 , 1.XI.1977; 1 ๆ, 20.X.1978; Vom, Plateau State, 2 ठิ ठิ, 7.XI.1977.

\section{Neuroleon ruber Michel \& Akoudjin, 2012}

First record for Nigeria. This is another species which was confused under the taxon $N$. nubilatus and recently isolated. Tibial spurs on hind legs are always present, whereas in $N$. nubilatus they are minute or absent. Jos is the southernmost locality in its range, situated to the south of the known localities in Guinea, Mali, Burkina Faso, and Cameroon.

Material: Jos, Plateau State, 1 ㅇ, 2.X.1978; 3 우우, 15.X.1978; 1 q, 21.X.1978; 1 Ô, 27.X.1978; 1 q, 17.XI.1978.

\section{Neuroleon linarixius (Navás, 1924)}

First record for Nigeria. The species is uncommon, known from Mali only in the literature, and from Burkina Faso (Prost, previously unpublished data). The new recording in Borno State is the easternmost in its range, $2000 \mathrm{~km}$ east of Sikasso in Southern Mali (Michel \& Letourmy, 2007), which significantly expands the known range eastwards. Michel \& 
Akoudjin (2012) consider that $N$. linarixius does not belong to the genus Neuroleon and that it should be reclassified within a new genus. In the meantime, the denomination stands.

Material: $37 \mathrm{~km}$ west of Maiduguri, Borno State, 1 9, 25.IX.1976.

\section{Myrmeleontini}

Hagenomyia tristis (Walker, 1853)

This is among the most common antlions in Africa, occurring often in large swarms during the day. It is distributed in the entire Afrotropical Region, including Madagascar. Medler (1980) mentioned it in Nigeria and material from Nigeria is preserved in the National Museums of Scotland (Whittington, 2002 as Myrmecaelurus tristis).

Material: Pandam Wildlife Park, Plateau State, 1 ô, 31.VII.1977; Jos, Plateau State, 1350 m, 1 ㅅ, 2 우우,

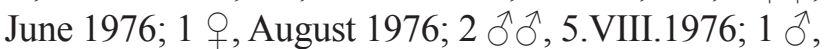
2 오, 18.VI.1977; 1 ㅇ, 1.XI.1977; 1 ふै, 25.VI.1978; 2 ठึगे, 25.X.1978.

\section{Myrmeleon obscurus Rambur, 1842}

This pit-building species is probably the most common Myrmeleon in Africa. It is present in a majority of the countries in the continent, abundant in cities as well as in rural areas. Medler (1980) mentioned its presence in Nigeria twice, as Morter obscurus and Myrmeleon obscurus. Fisher (1989) studied a population on the campus of Bayero University, Kano, Northern Nigeria. Thus it is notable that it is absent from Henwood's list, and uncommon in P. Beron's collection (five specimens).

Material: Jos, Plateau State, 1 , February 1978; Sabon Gida, Pai River Game Reserve, Plateau State, 1 ô, 3.III.1978; 1 \&, 11.IV.1978; Pandam Wildlife Park, Plateau State, $130 \mathrm{~km}$ south of Jos, 1 \&, 3.VII.1976; 1 ô, 1.X.1978.

\section{Myrmeleon quinquemaculatus Hagen, 1853 - Fig. 20}

This large species is a faunal element of Eastern and Central Africa. It reaches its western limit in Togo and has been collected in Benin. Common in Northern

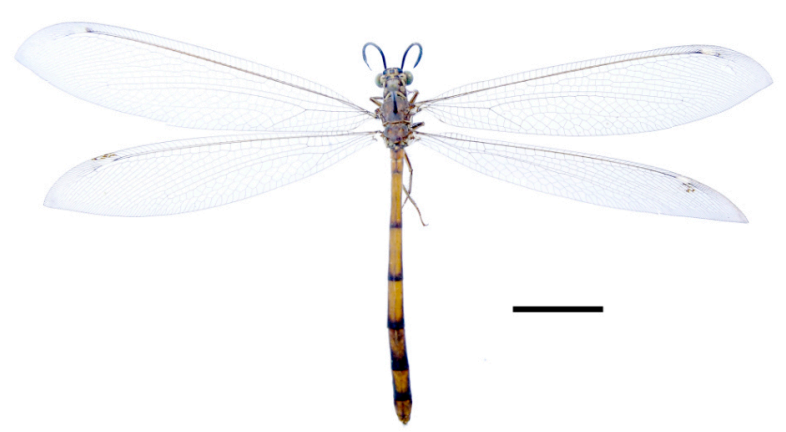

Fig. 20. Myrmeleon quinquemaculatus ô from Jos, May 1977. Scale bar: $1 \mathrm{~cm}$.

Cameroon, it is not rare in Nigeria (Medler, 1980 as two species under the names Macroleon polyzonus (Gerstaecker, 1885) and Macroleon quinquemaculatus; Whittington, 2002 as Distoleon quinquemaculatus).

Material: Jos, Plateau State, 1350 m, 2 ふึ่ึ, 2 우,

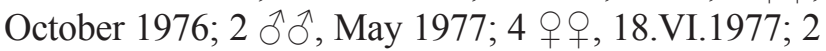
오오, 3.X.1978.

Myrmeleon n. sp. [under description]

This species is recorded for the first time from Nigeria. P. Beron collected nine specimens of a large Myrmeleon which cannot be related to any described species. As it happens, B. Michel is currently working on a description of this new taxon based on a number of individuals collected in Mali and in Burkina Faso between 2000 and 2009. The first author had collected the species in Burkina Faso in 1973 (unpublished to date). The general colour is orange red, the wings unmarked with a hyaline membrane and pale veins, and abdomen banded with a yellow ring on each abdominal segment.

Material: Jos, Plateau State, 1 đ, 1 q, June 1977; 1

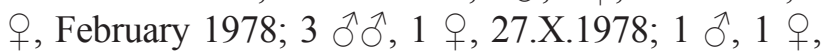
17.XI.1978.

Myrmecaelurini

Myrmecaelurus subcostalis Navás, 1914

First record for Nigeria. The Myrmecaelurus species inhabit dry and sandy areas. They are desert and subdesert species in Africa. M. subcostalis was described 


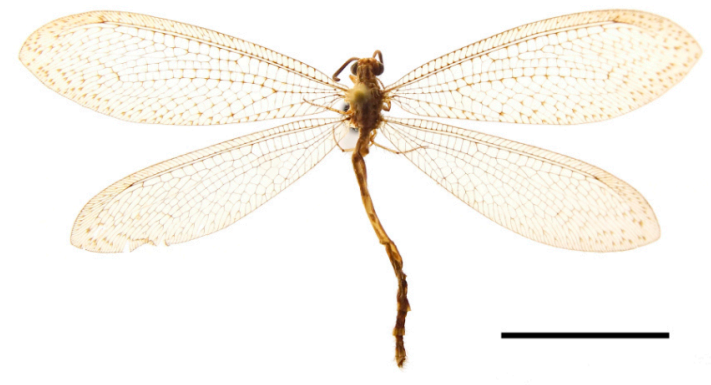

Fig. 21. Cueta martini $q$ from Jos, 27.X.1978. Scale bar: 1 $\mathrm{cm}$.

from "Haut Sénégal et Niger" (Navás, 1914c), a vast territory that included until 1912 all Sudan savannah territories under French administration between the River Senegal and Lake Chad. The first author collected several specimens in Burkina Faso (unpublished to date). Maiduguri is the southernmost locality.

Material: $37 \mathrm{~km}$ west of Maiduguri, Borno State, 2

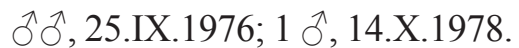

\section{Nesoleontini}

\section{Cueta martini Navás, 1914 - Fig. 21}

First record for Nigeria. This small representative of genus Cueta is described from Mali (Navás, 1914f). The first author collected three specimens in Burkina Faso (unpublished to date). Its presence in Northern Nigeria is not a surprise, although Jos is the easternmost and southernmost locality of the species, situated $1600 \mathrm{~km}$ eastwards of Sikasso in Mali, the closest published locality (Michel \& Letourmy, 2007).

Material: Jos, Plateau State, 1 Oै, 10.XI.1977; 1 , 15.X.1978; 1 ㅇ, 27.X.1978.

\section{Conclusion}

This comprehensive inventory of Neuroptera of Northeastern Nigeria is based primarily upon the specimens collected by P. Beron during the 1970s. It includes unpublished specimens preserved in public and private collections, and published records in the scientific literature. The scope of the inventory indicates that the region is home to 11 species of Ascalaphidae, 12 species of Palparidae, and 34 species of Myrmeleontidae, for a total of 57 species.

The genera Brevibarbis, Bankisus, and Capicua, as well as one species of Ascalaphidae, two species of Palparidae, and 16 species of Myrmeleontidae are reported from Nigeria for the first time, of which two species are new to science. The actual species number is certainly higher when compared to other parts of West Africa with comparable ecological conditions. For example, 54 species of Palparidae and Myrmeleontidae are known from Mali and 45 from Burkina Faso, two countries where inventories have been more systematic (Michel \& Akoudjin, 2013).

Dr Petar Beron brought a significant contribution to the knowledge of the fauna of Northeastern Nigeria, where political turmoil has made access very difficult since several years. With 296 specimens collected half a century ago and left unexploited in the National Museum of Natural History, Sofia, P. Beron's collection contributes significantly to the study of the investigated area. His contribution is evident from the fact that more than half of the species of the three families he collected are now new to the known fauna of Nigeria (19 of 35 species), nearly 50 years after he found them. Nine of these 35 species - just over a quarter of them (including two species new to science), were not yet described in the 1970s at the time the material was collected. Furthermore, P. Beron expanded the distribution of several other species to the Northern region. Just in the limited area east and north of the Niger and Benue rivers, he had already found more than half of the species listed for all Nigeria in the review of Michel \& Akoudjin (2013) 35 years later (35 of 63 species). From all of Northern Nigeria, only 21 species of the three families were known prior to the activity of $\mathrm{P}$. Beron in this country, including those published by Henwood (1977) during the insect sampling of P. Beron there. His discovery of a Bankisus species is a landmark since the genus was considered absent from West Africa. The specimen of Brevibarbis argyroptera collected by P. Beron is the first recorded from a Sudan savannah area. Important also is the presence of Centroclisis lineatipennis which was not known north of Brazzaville, Republic of the Congo. The identification of the collection of Petar Beron provides an opportunity to expand knowledge about the ranges of 14 species. The material contains 21 further localities in the four cardinal directions: the easternmost for the ranges of ten species, the southernmost of nine species, and the northernmost and westernmost locality of Centro- 
clisis lineatipennis. As a result, the limits of the known ranges of eight species shift outward $1000 \mathrm{~km}$, including for Distoleon pullus and Neuroleon linarixius by 2000 or more kilometres.

Long-term collection, albeit uneven, in Plateau State, and especially in Jos area, makes it possible to determine species with higher abundance. Most numerous in the samples of P. Beron is Neuroleon nubilatus with 83 specimens or $28 \%$ of all material, followed by Distoleon harpalyce with 49 specimens or $17 \%$. Almost half or 15 of the 35 species collected were found with a single specimen each, and this indicates a wider spectrum of species diversity.

Petar Beron systematically concentrated his collections in a delimited geographical area and over a defined period of time. Henwood's published material was collected during the same period in the same localities. Together they provide an historical snapshot of the diversity of the Neuropteran fauna in Northeastern Nigeria a half century ago. The data are not available to date to assess whether faunistic changes that may have occurred in the interval either because of climate change or due to political, social and economic upheavals. Consequently, the snapshot of Northeastern Nigerian fauna provided by the field work of Beron and Henwood as analysed and summarised here by the authors may become the reference for all future investigation on changes in the Neuropteran fauna, and more generally in the entomological records in the dry savannahs of West Africa.

In the presentation of the geographical distribution of species identified in Northern Nigeria, the presence of six species in Burkina Faso is reported for the first time based on collections made by the first author: Creoleon nigrithorax sp. n., Distoleon pullus, Neuroleon linarixius, Myrmeleon sp. (a new species under description), Myrmecaelurus subcostalis, and Cueta martini. First records in Burkina Faso include also the genera Myrmecaelurus and Cueta, and the tribe Nesoleontini.

In an overview of the genus Bankisus, the ranges of the species have been critically discussed and some records have been clarified and corrected. Based on this, an original map of the distribution of the genus was prepared. The occurrence of Bankisus in Yemen is discussed, and reports on the distribution of the genus in Ghana, the Republic of the Congo, and Zambia are found to be erroneous. Bankisus oculatus is reported for the first time from the Democratic Republic of the Congo.
Gymnoleon gaillardi Navás, 1912, considered a synonym of Gymnoleon exilis Banks, 1911, should instead be a synonym of Gymnoleon externus (Navás, 1911) (syn. n.) based on our examination of the holotype of G. gaillardi. Two species of Palparidae, Palpares cataractae and Palpares radiatus, are deleted from the list of Nigerian fauna.

\section{Acknowledgements}

We are first of all grateful to Petar Beron (Sofia) for sampling and providing us a rich and valuable collection of the three families collected during his stay in Nigeria. We would like to thank Stoyan Beshkov (Sofia) for numerous photographs of the genitalia of Bankisus beroni sp. n., which were used in their drawing. We are much indebted to Assen Ignatov (Sofia) for the photographs of the specimens and the drawing of the pronotum of Creoleon nigrithorax $\mathbf{s p .} \mathbf{n}$., as well as for help in preparing the map of the distribution of the genus Bankisus. Our gratitude is also directed to Andrew Whittington for giving access to the collections of the National Museums of Scotland, Edinburgh. We are thankful to Bruno Michel (Montpellier) for a photograph of Distoleon languidus from Mali. Sincere thanks to Horst Aspöck and Ulrike Aspöck (both Vienna) for discussing the genital terminology and homologisation of the genital structures of Myrmeleontidae. Cordial thanks to Odile Frank for checking the manuscript for linguistic inaccuracies.

\section{References}

Ábrahám L. 2009 A new Bankisus Navás, 1912 species from Morocco (Neuroptera: Myrmeleontidae). Acta Phytopathologica et Entomologica Hungarica 44 (2): 423-429.

Ábrahám L. 2017 New data to the Moroccan Myrmeleontiformia (Nemopteridae, Myrmeleontidae, Ascalaphidae) fauna. Natura Somogyiensis 30: 75-138.

Ábrahám L., Giacomino M. 2020 A little known and synonym ant-lions. 2 (Neuroptera: Myrmeleontidae). Natura Somogyiensis 34: 21-72. https://doi.org/10.24394/NatSom.2020.34.21 [

Akoudjin M., Michel B. 2011 A new species of Palpares Rambur (Neuroptera: Myrmeleontidae) 
with an identification key to the species of West Africa. Zootaxa 2792: 33-40.

Aspöck U., Aspöck H. 2008 Phylogenetic relevance of the genital sclerites of Neuropterida (Insecta: Holometabola). Systematic Entomology 33 (1): 97-127. https://doi.org/10.1111/j.1365-3113.2007.00396.x [

Badano D., Aspöck U., Aspöck H., Ceretti P. 2017 Phylogeny of Myrmeleontiformia based on larval morphology (Neuropterida: Neuroptera). Systematic Entomology 42 (1): 94-117. https://doi.org/10.1111/syen.12200 [

Banks N. 1911 Notes on African Myrmeleonidae. Annals of the Entomological Society of America 4 (1): 1-29.

Banks N. 1913a The neuropterous genus Palpares. Annals of the Entomological Society of America 6 (2): 171-195.

Banks N. 1913b Notes on African Myrmeleonidae. Journal of the New York Entomological Society 21 (2): 149-157.

Dalman J.W. 1823 Analecta entomologica. Typis Lindhianis, Holmiae, vii+104 pp.

Dunger G.T. 1965 Wase Rock - its history, geology, fauna and climbs. The Nigerian Field 30 (4): 148-184.

Esben-Petersen P. 1915 New species of neuropterous insects in Danish collections. Videnskabelige Meddelelser fra Dansk naturhistorisk Forening i Kjøbenhavn 66: 175-181.

Esben-Petersen P. 1916 Notes concerning African Myrmeleonidae. I. Arkiv för Zoologi 10 (15): $1-22$.

Esben-Petersen P. 1927 New and little-known species of Neuroptera in British collections. Part III. Annals and Magazine of Natural History 9, 20 (118): 343-350.

Esben-Petersen P. 1936 Neuroptera from Belgian Congo. Revue suisse de zoologie 43 (8): 199-206.

Fisher M. 1989 Antlion life cycles in Nigeria. Journal of Tropical Ecology 5 (2): 247-250.

Gerstaecker A. 1885 Vier Decaden von Neuropteren aus der Familie Megaloptera Burm. Mittheilungen des naturwissenschaftliches Vereins von Neu-Vorpommern und Rügen in Greifswald 16: 1-49.

Gerstaecker A. 1888 Weitere Beiträge zur Artenkenntniss der Neuroptera Megaloptera. Mittheilungen des naturwissenschaftliches Vereins für Neu-Vorpommern und Rügen in Greifswald 19 [1887]: 89-130.

Gerstaecker A. 1894 Ueber neue und weniger gekannte Neuropteren aus der Familie Megaloptera Burm. Mittheilungen des naturwissenschaftliches Vereins für Neu-Vorpommern und Rügen in Greifswald 25 [1893]: 93-173.

Hagen H. 1853 4. August. Gesamtsitzung der Akademie. Hr. Peters berichtete über die von ihm gesammelten und von Hrn. Hermann Hagen bearbeiteten Neuropteren aus Mossambique. Bericht über die zur Bekanntmachung geeigneten Verhandlungen der Königl. Preuss. Akademie der Wissenschaften zu Berlin 1853: 479-482.

Hagen H. 1866 Hemerobidarum synopsis synonymica. Entomologische Zeitung von dem entomologischen Vereine zu Stettin 27 (10-12): 369-462.

Handschin E. 1963 Beitrag zur Kenntnis der Neuropterenfauna von Madagascar. Mitteilungen der Schweizerischen Entomologischen Gesellschaft 35 [1962] (3-4): 211-226.

Henwood G.A. 1977 Ant lions of North East Nigeria. The Nigerian Field 42 (3): 111-117 [reproduced in The Bulletin of the Amateur entomologist's Society, 1979, 38 (323): 52-57].

Hölzel H. 1983 Insects of Saudi Arabia. Neuroptera: Fam. Myrmeleonidae (Part 2). Fauna of Saudi Arabia 5: 210-234.

Hölzel H. 1998 Zoogeographical features of Neuroptera of the Arabian peninsula). In: Panelius S. (ed.) Neuropterology 1997. Proceedings of the Sixth International Symposium on Neuropterology. Helsinki, Finland, 13-16 July 1997. Acta Zoologica Fennica 209: 129-140.

Hölzel H. 2002 Neuroptera collected by the German Yemen expeditions 1996, 1998 and 2000 (Neuroptera: Chrysopidae, Hemerobiidae, Berothidae, Mantispidae, Nemopteridae, Myrmeleontidae, Ascalaphidae). Esperiana 9: 129-146.

Insom E., Carfi S. 1989 Taxonomic studies on Palparini (sensu Markl, 1954). I: The genus Palpares Rambur, 1842 partim (Neuroptera: Myrmeleontidae) with the proposal of its division and description of new genera. Neuroptera international 5 [1988] (2): 57-78.

Jones J.R. 2014 Taxonomic revisions of six genera of entire-eyed owlflies (Ascalaphidae: Haplogleniinae), and first large-scale phylogeny of the owlflies. Dissertation submitted to the Office of Graduate and Professional Studies of Texas A\&M 
University in partial fulfillment of the requirements for the degree of Doctor of Philosophy. Texas A\&M University, College Station, $1088 \mathrm{pp}$. https://hdl.handle.net/1969.1/154034 [

Jones J.R. 2019 Total-evidence phylogeny of the owlflies (Neuroptera, Ascalaphidae) supports a new higher-level classification. Zoologica Scripta 48 (6): 761-782.

https://doi.org/10.1111/zsc.12382 [

Kemal M., Koçak A.Ö. 2013 Bankisus oculatus Navas of Limpopo Province (South Africa) (Neuroptera, Myrmeleontidae). Cesa News 90: 16-17.

Kimmins D.E. 1949 Notes on Ascalaphidae in the British Museum collections, with descriptions of new species. Annals and Magazine of Natural History 12, 2 (13): 1-29.

Klug F. 1834 Decas 4. In: Ehrenberg C.G. (ed.) Symbolae physicae seu icones et descriptiones insectorum quae ex itinere per Africam borealem et Asiam occidentalem. Officina academica, Berolini, plates 35-36.

Kolbe H.J. 1897 Neuropteren. Die Netzflügler. In: Möbius K. (ed.) Deutsch-Ost-Afrika. Wissenschaftliche Forschungsresultate über Land und Leute ostafrikanischen Schutzgebiets und der angrenzenden Länder. Band IV. Die Thierwelt OstAfrikas und der Nachbargebiete. Wirbellose Thiere. Lieferung 8. Dietrich Reimer, Berlin, 1-42.

Krivokhatsky V.A. 2005 Black-striped morphs of antlions (Neuroptera, Myrmeleontidae). Entomologicheskoe obozrenie 84 (1): 159-163. (In Russian)

Latreille P.A. 1829 in Cuvier G. Le règne animal distribué d'après son organisation, pour servir de base a l'histoire naturelle des animaux et d'introduction a l'anatomie comparée. Nouvelle edition, Tome V. Déterville, Paris, xxiv+556 pp.

Machado R.J.P., Gillung J.P., Winterton S.L., GarzónOrduña I.J., Lemmon A.R., Lemmon E.M., Oswald J.D. 2018 Owlflies are derived antlions: anchored phylogenomics supports a new phylogeny and classification of Myrmeleontidae (Neuroptera). Systematic Entomology 44 (2): 418-450.

https://doi.org/10.1111/syen.12334 [

Mansell M.W. 1985 The ant-lions of southern Africa (Neuroptera: Myrmeleontidae). Introduction and genus Bankisus Navás. Journal of the Entomological Society of Southern Africa 48 (1): 189-212.

Mansell M.W. 1987 The ant-lions of southern Africa (Neuroptera: Myrmeleontidae): genus Cymothales
Gerstaecker, including extralimital species. Systematic Entomology 12 (2): 181-219.

Mansell M.W. 1996 The antlions of southern Africa (Neuroptera: Myrmeleontidae): genus Palparellus Navás, including extralimital species. African Entomology 4 (2): 239-267.

Mansell M.W. 2018 Antlions of southern Africa: Syngenes Kolbe, 1897, with descriptions of two new species and comments on extra-limital taxa (Neuroptera: Myrmeleontidae: Acanthaclisini). Zootaxa 4497 (3): 346-380.

https://doi.org/10.11646/zootaxa.4497.3.2 〔

Medler J.T. 1980 Insects of Nigeria - check list and bibliography. Memoirs of the American Entomological Institute 30: 919 pp. [Neuroptera, p. 136-139].

Michel B. 2019 Revision of the genus Disparomitus van der Weele, 1909 with descriptions of four new species (Neuroptera, Ascalaphidae). Zootaxa 4551 (1): $1-39$.

https://doi.org/10.11646/zootaxa.4551.1.1 [

Michel B., Akoudjin M. 2011 Reinstatement of the genus Capicua Navás with descriptions of two new species (Neuroptera, Myrmeleontidae). Zootaxa 3032: 40-46.

Michel B., Akoudjin M. 2012 Review of Neuroleon Navás of West Africa with descriptions of four new species (Neuroptera, Myrmeleontidae). Zootaxa 3519 (1): 32-52.

Michel B., Akoudjin M. 2013 Overview of the knowledge of antlions and owlflies (Neuroptera: Myrmeleontidae, Ascalaphidae) of West Africa. Açoreana Suplemento 9: 39-56.

Michel B., François A. 2019 Contribution to the knowledge of the Neuroptera of the Oriental region of Morocco. In: Weihrauch F., Frank O., Gruppe A., Jepson J.E., Kirschey L., Ohl M. (eds) Proceedings of the XIII International Symposium of Neuropterology, 17-22 June 2018, Laufen, Germany. Osmylus Scientific Publishers, Wolnzach, 181-186.

https://doi.org/10.5281/zenodo.3569399 [

Michel B., Letourmy P. 2007 Characterisation of a West African Myrmeleontinae assemblage (Neuroptera Myrmeleontidae): first evidence of a relationship between adult occurrences and climatic conditions. Tropical Zoology 20: 197-209.

Michel B., Mansell M.W. 2010 Revision of the genus Ganguilus Navás (Neuroptera, Myrmeleontidae) 
with descriptions of three new species. Zootaxa 2386: 1-24.

Michel B., Clamens A.-L., Béthoux O., Kergoat G.J., Condamine F.L. 2017 A first higher-level time-calibrated phylogeny of antlions (Neuroptera: Myrmeleontidae). Molecular Phylogenetics and Evolution 107: 103-116. https://doi.org/10.1016/j.ympev.2016.10.014 〔

Navás L. 1911 Notes sur quelques Névroptères d'Afrique. I. Revue Zoologique Africaine 1 (2): 230-244.

Navás L. 1912a Notas sobre Mirmeleónidos (Ins. Neur.). Brotéria, Serie Zoologica 10: 29-75, 85-97.

Navás L. 1912b Myrméléonides (Ins. Névr.) nouveaux ou peu connus. Annales de la Société scientifique de Bruxelles 36 (2): 203-248.

Navás L. 1912c Trois Myrméléonides (Neur.) nouveaux de l'Afrique. Fauna exotica 1 (12): $45-46$.

Navás L. 1912d Notes sur quelques Névroptères. III. Névroptères d'Afrique nouveaux ou critiques. Insecta (Rennes) 2 (16): 68-80.

Navás L. 1912e Notes sur quelques Névroptères d'Afrique. III. Myrméléonides nouveaux. Revue Zoologique Africaine 2 (1): 35-43.

Navás L. 1914a Notes sur quelques Névroptères du Congo Belge. Revue Zoologique Africaine 3 (2): 365-377.

Navás L. 1914b Voyage de Ch. Alluaud et R. Jeannel en Afrique Orientale (1911-1912). Résultats scientifiques. Insectes Névroptères. I. Planipennia et Mecoptera. Librairie Albert Schulz, Paris, 52 pp.

Navás L. 1914c Neuroptera nova africana. III series. Memorie dell'Accademia Pontificia dei Nuovi Lincei 1, 32: 99-108.

Navás L. 1914d Notes sur quelques Névroptères du Congo Belge. II. Revue Zoologique Africaine 4 (1): 91-100.

Navás L. 1914e Neuroptera nova africana. I series. Memorie dell'Accademia Pontificia dei Nuovi Lincei 1, 32: 81-90.

Navás L. 1914f Neurópteros nuevos de África. Memorias de la Real Academia de Ciencias y Artes de Barcelona 3, 10 (30): 627-653.

Navás L. 1921 Comunicaciones entomológicas. 4. Insectos exóticos nuevos, críticos o poco conocidos. Revista de la Academia de ciencias exactas fisico-quimicas y naturales de Zaragoza 6 (1): 61-81.
Navás L. 1923 Quelques Myrméléonides (Ins. Névr.) d'Afrique. Annales de la Société scientifique de Bruxelles 43 (1): 143-147.

Navás L. 1924 Névroptères d'Afrique. Annales de la Société scientifique de Bruxelles 43 (1): 375-380.

Navás L. 1926 Insecta nova. Series XI. Memorie della Pontificia Accademia delle scienze, Nuovi Lincei 2, 9: 101-110.

Navás L. 1931 Insectes du Congo Belge. Revue de Zoologie et de Botanique Africaines 20 (3): 257-279.

Navás L. 1932 Insectes du Congo Belge. Série VII. Revue de Zoologie et de Botanique Africaines 22 (3): 269-290.

Navás L. 1936 Insectes du Congo Belge. Série IX. Revue de Zoologie et de Botanique Africaines 28 (3): 333-368.

Navás L. 1940 Neurópteros nuevos o críticos. In: VI Congreso international de entomología, Madrid, 612 de septiembre de 1935. Tomo I. Laboratorio de entomología del Museo Nacional de Ciencias Naturales, Madrid, 97-102.

Oswald J.D. 2018 Neuropterida species of the World. A catalogue and monograph of the species and subspecies of the extant and extinct Neuroptera, Megaloptera, Raphidioptera, and Glosselytrodea (Insecta: Neuropterida) of the World. Lacewing Digital Library, Research Publication No. 1. Version 6. Release 6.6.

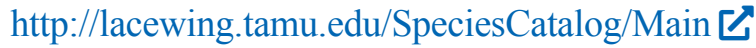
(accessed 7 October 2020)

Péringuey L. 1910 Description of a new or little known species of the Hemerobiidae (order Neuroptera) from South Africa. Annals of the South African Museum 5 (8): 433-454.

Prost A. 1995 Révision des Palparinae d'Afrique de l'Ouest (Neuroptera, Myrmeleontidae). Bulletin de la Société entomologique de France 100 (1): 79-107.

Prost A. 1999 Les Acanthaclisinae d'Afrique occidentale et centrale [Neuroptera, Myrmeleontidae]. Revue française d'Entomologie (N.S.) 20 [1998] (4): 157-173.

Prost A. 2010 Patterns of distribution of the Palparini (Neuroptera: Myrmeleontidae: Palparinae) in the northern half of Africa. Faunal transitions and regional overlaps. In: Devetak D., Lipovšek S., Arnett A.E. (eds) Proceedings of the Tenth International Symposium on Neuropterology. Piran, Slovenia, 2008. University of Maribor, Maribor, 257-266. 
Prost A. 2013 The genus Ascalaphus (Fabricius, 1775) (Neuroptera, Ascalaphidae) in Africa. Açoreana Suplemento 9: 57-72.

Prost A. 2018 Révision du taxon Parapalpares latipennis (Rambur, 1842) et description d'une espèce nouvelle d'Angola (Neuroptera, Myrmeleontidae, Palparinae). Bulletin de la Société entomologique de France 123 (1): 65-71.

Prost A. 2019 The genus Nosa Navás, 1911 (Neuroptera, Myrmeleontidae, Palparinae). In: Weihrauch F., Frank O., Gruppe A., Jepson J.E., Kirschey L., Ohl M. (eds) Proceedings of the XIII International Symposium of Neuropterology, 17-22 June 2018, Laufen, Germany. Osmylus Scientific Publishers, Wolnzach, 129-143. https://doi.org/10.5281/zenodo.3569391 ¿

Rambur P. 1842 Histoire naturelle des insectes. Névroptères. Librairie encyclopédique Roret, Paris, xviii +534 pp.

Stange L.A. 1994 Reclassification of the New World antlion genera formerly included in the tribe Brachynemurini (Neuroptera: Myrmeleontidae). Insecta Mundi 8 (1-2): 67-119.

Stange L.A. 2004 A systematic catalog, bibliography and classification of the world antlions (Insecta: Neuroptera: Myrmeleontidae). Memoirs of the American Entomological Institute 74: 565 pp.

Stitz H. 1912 Palpares aus der Sammlung des Berliner Museums. Mitteilungen aus dem Zoologischen Museum in Berlin 6 (1): 103-116.

Taschenberg E. 1879 Die Arten der Gattung Myrmecoleon Br. und Ascalaphus des Zoolog. Museums der Universität Halle. Zeitschrift für die gesamte Naturwissenschaft 52: 174-231.

Tillyard R.J. 1918 Mesozoic insects of Queensland. No. 3. Odonata and Protodonata. Proceedings of the Linnean Society of New South Wales 43 (171): 417-436.
Tjeder B. 1954 Genital structures and terminology in the order Neuroptera. Entomologiske Meddelelser 27 (1): 23-40.

Tjeder B. 1980 Ascalaphidae (Neuroptera) from Senegal and the Gambia. Entomologica scandinavica 11 (4): 401-412. https://doi.org/10.1163/187631280794710006 [

Van der Weele H.W. 1904 New and little-known Neuroptera. Notes from the Leyden Museum 24 (4): 203-215.

Van der Weele H.W. 1909 Ascalaphiden monographisch bearbeitet. Collections zoologiques du Baron Edm. de Selys Longchamps. Catalogue systématique et descriptif 8 [1908]: $326 \mathrm{pp}$.

Walker F. 1853 List of the specimens of neuropterous insects in the collection of the British Museum. Part II (Sialidae-Nemopterides). British Museum, London, 193-476.

Wang X., Ao W., Wang Z., Wan X. 2012 Review of the genus Gatzara Navás, 1915 from China (Neuroptera: Myrmeleontidae). Zootaxa 3408 (1): 34-46.

Whittington A.E. 2002 Resources in Scottish Neuropterology. Acta Zoologica Academiae Scientiarum Hungaricae 48 (Supplement 2): 371-387.

Winterton S.L., Lemmon A.R., Gillung J.P., Garzón I.J., Badano D., Bakkes D.K., Breitkreuz L.C.V., Engel M.S., Lemmon E.M., Liu X., Machado R.J.P., Skevington J.H., Oswald J.D. 2017 Evolution of lacewings and allied orders using anchored phylogenomics (Neuroptera, Megaloptera, Raphidioptera). Systematic Entomology 43 (2): 330-354.

https://doi.org/10.1111/syen.12278 [

Zhan Q., Wang X. 2012 First record of the genus Bankisus Navás, 1912 in China, with the description of a new species (Neuroptera, Myrmeleontidae). ZooKeys 204: 41-46.

https://doi.org/10.3897/zookeys.204.3108_ 